\title{
The politics of energy landscapes: the influence of local anti-wind initiatives on state policies in Saxony, Germany
}

\author{
Gerd Lintz ${ }^{*}$ (1) and Markus Leibenath
}

\begin{abstract}
Background: In recent years, landscapes in many countries have been transformed by efforts to fight global warming, specifically the shift towards renewable energies such as wind power. This development has been met by growing opposition from local citizens and their initiatives. There is an ongoing debate about whether and how such protests have a real impact on the development of energy landscapes.

Methods: Drawing on the rare case of a state government scaling back ambitious targets for the expansion of renewables, the authors were able to analyse the impact of protests in the context of regional spatial planning and, particularly, state policy-making on energy. Conceptually drawing on the Advocacy Coalition Framework and using the method of causal-process tracing, the qualitative study investigates related interactions and decision-making processes in the federal state of Saxony, Germany, between 2011—when targets were increased — and 2013_when targets were scaled back.

Results: The findings show that the protests grew significantly when the raised expansion targets for renewables were translated into a higher number of potential wind farm sites. The protests, which primarily referred to landscapes, were well-organised and creative. Activists worked through a range of channels across various contexts and several levels of the politico-administrative system, in particular approaching regional spatial planners and a wide range of politicians. In the end, the protests (along with other factors) significantly contributed to the readjustment by the Saxon coalition government of its energy and climate policy and thus to a slowdown of energy-related landscape change.

Conclusions: The study confirms that the influence of protesters can greatly exceed the previously studied participation in the planning of sites and the approval process for individual wind farms. Also highlighting other relevant co-influential factors, the paper contributes to the development of a middle-range theory of the impact of local opposition to wind power in the context of energy landscapes.
\end{abstract}

Keywords: Energy policy, Spatial planning, Landscape policy, Wind power, Renewables, Protest

\section{Background}

In recent years, landscapes in many countries have been transformed by efforts to fight global warming, specifically the shift towards renewable energies such as wind power [1]. This development has been met by growing opposition, especially from local citizens and their initiatives. On the one hand, many authors see such protests and

\footnotetext{
* Correspondence: g.lintz@ioer.de

Leibniz Institute of Ecological Urban and Regional Development (IOER),

Research Area: Landscape Change and Management, Weberplatz 1, 01217 Dresden, Germany
}

opposition as an impediment to the expansion of renewables, considered a vital step in combating global warming (e.g. [2]). Other authors welcome the protests as serving to protect age-old cultural landscapes (e.g. [3]). Yet the actual impact of local protests against wind farms has not been satisfactorily investigated, specifically regarding the influence on governmental energy policy.

The study seeks to improve our knowledge in this regard, particularly the political dimension in a complex governance system structured, for instance, by several politicoadministrative levels and encompassing many different 
institutionalised sectoral and spatial policies. Based on a qualitative study conducted in the German state of Saxony, the paper aims to explain the rare case of a government scaling back its expansion target for renewables. In 2011, the year of the Fukushima nuclear disaster and the declaration of Germany's phase out of nuclear energy, the Saxon government ambitiously expanded its target; yet two years later, the adoption of the Saxon Energy and Climate Programme in 2013 saw a partial scaling back of this target, greatly reducing the planned contribution of wind power. Given the rise in local protests against wind energy exactly in that period, the study explores the complex decision-making processes at state and regional level by focusing on one of the four regional planning associations (Upper Elbe Valley/East Ore Mountains). The research question is whether and how the local protests actually impacted on the decision taken by Saxony's coalition government to scale back their ambitious target for the expansion of renewables. Conceptually, the study draws on the Advocacy Coalition Framework while causal relationships are uncovered using the causal-process tracing method.

The paper is structured as follows. In the remainder of this section, a brief overview is given of the state of research on local anti-wind protests and the identified research gap. Then, the study's conceptual approach is presented, in particular the Advocacy Coalition Framework. In "Methods-case study and causal-process tracing", we describe the adopted methods. Following a presentation of the empirical results in the form of a comprehensive storyline in "Results-the comprehensive storyline", these findings are discussed in greater depth with regard to causality in "Discussion-tracing causality". Finally, some conclusions are drawn.

\section{The literature on local anti-wind protests-the research gap}

There exists a growing body of literature on local opposition to wind power in the context of energy landscapes. One focus of research has been to explain the rather low local acceptance of wind power in general (e.g. [4]), specifically with regard to the NIMBY argument (e.g. [5]), the often negative perception of wind power (e.g. [6]), planning procedures and participation (e.g. [7]), community involvement and developer transparency (e.g. [8]), organisation and ownership (e.g. [9]) as well as community benefits (e.g. [10]). Based on these various explanations, suggestions are often made on how to foster acceptance.

Local protests have also been studied in view of the fact that opposition to wind power projects is largely expressed through citizens' initiatives [11]. As a rule, such initiatives are formed when local people become aware that a negatively perceived wind power project might be sited in the vicinity of their towns or homes. Usually a wide range of arguments are voiced against the project in terms of nature protection, excessive noise and infrasound, etc. Yet the primary argument is very often about safeguarding the landscape. Toke et al. [12, p. 1132] even state that: "Strong and effective opposition to wind developments is always primarily rooted in landscape values." The aim of the initiatives is to avoid or at least mitigate the negative impacts of the project by trying to influence those responsible for crucial decisions. Ogilvie and Rootes [13] as well as Marg et al. [14] provide many examples of how such initiatives are organised along with their various forms of action.

However, comparatively little research has been conducted on the actual impact of protests by local citizens' initiatives. So far there are mixed results regarding protests in various contexts with a tendency to acknowledge that protests can matter. In their helpful comparative investigation of six countries, Toke et al. [12] see landscape protection organisations, which include citizens' initiatives, as a key factor in their model to explain differences in wind power deployment outcomes. Yet this rather abstract comparative study does not trace the impact of these organisations in the respective countries under investigation. Moreover, state energy policy is not explicitly considered. The impact of protests is confirmed by Reusswig et al. [15] in the relatively simple context of decision-making within a small German municipality. They traced how, under otherwise very favourable circumstances, local protest halted the detailed plans of a municipality to build three wind turbines before the approval procedure could be reached.

With regard to the expansion of wind power, most detailed investigations have focussed on the administrative and legal channels of participatory processes regarding individual projects (for public participation in general, see e.g. [16]). For instance, Aitken et al. [17] investigated the decision-making process around a planning application for a wind power development in Scotland. They showed that local opposition merely had a delaying effect; ultimately, the concerns expressed in many objection letters had little influence. Rydin et al. [18] came to a similar assessment when analysing the decision-making process for six major wind power developments in the UK, classified as Nationally Significant Infrastructure Projects. They concluded that the Examining Authority focussed on mitigating the negative impact of the projects while allowing the developments to proceed. The authors call this a "how not whether" approach (also refer to [19, pp. 61, 65]. One recent German study came to a different conclusion in its survey of appeals made by NGOs (who often support local protests) against approvals for wind turbines under the Federal Immission Control Act [20]. Of the 24 appeals decided in 2013-2016, seven were successful (29\%) and four were partly successful (17\%), with only 13 cases being rejected (54\%). 
Critically discussing the findings of Aitken et al. [17] on protesters' lack of influence on decision-making, Ogilvie and Rootes [13] studied four cases of anti-wind farm protests in England in order to understand the various ways in which local protestors can affect the approval of planning applications. Two of the four protests were successful. Similar to the mentioned study by Reusswig et al. [15] and in contrast to Aitken et al. [17], the authors highlight the importance of local activists, who used direct argumentation and community mobilisation in the successful cases to influence two levels of decision-making, namely the local authority and the public enquiry. In particular, the campaigns exerted political pressure on locally elected decision-makers and raised money to hire experts in support of their cause. Ogilvie and Rootes [13] also highlight the relevance of informal contacts that precede public enquiries. Interestingly, Aitken et al. [17] as well as Rydin, Lee and Lock [18] believe that national (or state) policies in favour of wind power are the reason for the relatively low influence (as they see it) of local protests against wind power developments.

Thus the question arises whether local anti-wind power protests can force national or state authorities to revise their energy and climate policy goals, specifically the expansion of wind power generation. Here, the authors are only aware of one study by Bues [21] comparing the influence of local protest initiatives on wind energy policy in the German state of Brandenburg with the Canadian Province of Ontario. While the two cases show many similarities, Bues identified (in particular) the different spatial planning approaches and spatial discursive strategies employed as factors contributing to the failure of the protest campaign in Brandenburg and the success of the one in Ontario. Obviously, additional cases have to be investigated to learn more about the influence of local protest initiatives on state wind power policies.

\section{Conceptual background-the Advocacy Coalition Framework}

The study focuses on two presumably related events: protests by local initiatives against wind power as a potential cause of policy change (possible causal factor) and the reduction of targets for the expansion of renewables and wind power by the state government (policy change to be explained). It is important to recognise that such change takes place in a complex governance system characterised by diverse actors dynamically interacting within sophisticated institutional structures as well as by a time-consuming and incremental process of decision-making (cf. [22-24]). More specifically, the study draws on the widely used complex and process-oriented Advocacy Coalition Framework, which explicitly seeks to explain policy change (as in the case at hand) by examining a wide political and institutional context encompassing a large set of possible factors [25].
This framework, which originates in environmental research, is designed to analyse long-term fundamental policy change. Nevertheless, it can be usefully applied to investigate the less fundamental impact of protests within a twoyear period. In order to structure the multiplicity of actors involved in policy-making, the approach aggregates these into "advocacy coalitions", which gather together actors in competing informal networks characterised by similar beliefs, thinking and policy intentions (e.g. [25, pp. 192, 196]). For instance, in the case at hand we can distinguish advocacy coalitions for and against wind power. Such coalitions may include heterogeneous actors from the spheres of government/public administration, parliament and political parties. Members may be associated with various politico-administrative levels or diverse sectoral policies and spatial policy. Finally, advocacy coalitions may include non-governmental organisations, citizens' initiatives and the media.

The framework highlights four partly overlapping paths to policy change. The first of these is policy-oriented learning within one or more advocacy coalition, originally the key feature of the framework. It is defined as "relatively enduring alternations of thought or behavioural intentions that result from experience and/or new information and that are concerned with the attainment or revision of policy objectives" [26, p. 123, after 25, p. 198]. This path is usually connected to time periods of at least a decade. In the present study, we can hardly expect to encounter this kind of learning. The second path is an external shock that exerts a large influence. Such shocks include "changes in socioeconomic conditions, regime change, outputs from other subsystems, or disaster" [25, pp. 198 f.]. These have the power to "shift agendas, focus public attention, and attract the attention of key decisionmaking sovereigns" [25, p. 199]. Moreover, they can lead to rapid changes in subsystem structures and beliefs as well as in the distribution of resources, so that a formerly minority coalition may even become dominant. The third path refers to internal shocks that directly affect actors within the advocacy coalitions. While similar to external shocks, their impact is more directly felt. In the fourth path to policy change, competing advocacy coalitions negotiate an agreement [27, p. 124]. This may happen, for instance, in the case of a damaging stalemate when coalitions are balanced in terms of their resources or a formerly blocking advocacy coalition undergoes policy-oriented learning.

Alongside these four paths to policy change, it is important to note two further key elements of the Advocacy Coalition Framework. The first is the existence of relatively stable institutional rules, which structure the interaction between actors. The second, and most significant for the present study is the premise that a coalition's resources, which determine its potential influence, can change rather quickly. These include, for example, formal 
legal authority to make policy decisions (e.g. ministerial competence), public opinion, information, mobilisable troops, financial resources and skilful leadership [25, p. 203].

\section{Methods-case study and causal-process tracing}

Analysing the influence of local protests against wind power is complex due to the many factors involved. Hence, qualitative case studies generally seem the most appropriate approach [28]. The current study on Saxon energy and climate policy investigates a rare case of policy change defined by two central events: A concrete policy output, which potentially triggered protests, and a concrete change to the initial policy output, which was potentially influenced by these protests. Here our particular focus is on the protests in the planning region of Upper Elbe Valley/East Ore Mountains (Oberes Elbtal/ Osterzgebirge) as these played a special role.

As the Advocacy Coalition Framework is already oriented towards the policy process, it is appropriate to use the empirical method of causal-process tracing [28]. This goes beyond a simple descriptive narrative of events. Instead, such tracing is intended to collect and analyse observations that determine "the temporal order by which the causal process unfolds", provide "certainty and density with respect to the pathway leading from cause to effect", and specify the underlying motivations or "mechanisms that link causes and effects" [28, p. 81]. The method aims to establish causal relationships within the case and to achieve a possibilistic generalisation [28, pp. $79 \mathrm{ff}$.]. In our case study we can thus answer two questions simultaneously: whether there was indeed an influence and how this influence materialised.

The empirical work was conducted in two stages. In an earlier project, the authors and their colleague Peter Wirth investigated wind power controversies and the participation of interest groups in wind power planning in Saxony, particularly in the planning region of Upper Elbe Valley/ East Ore Mountains. Six semi-structured interviews were conducted in the period 2011-2014 with opponents and proponents of wind power, the planning bureau of this regional planning association as well as the district administration Pirna. In 2013 the authors systematically analysed 301 newspaper articles published in the newspaper Sächsische Zeitung between March 2012 and April 2013, the time of the most intensive public debate. Moreover, as moderators of a working group that, between November 2013 and November 2014, brought together opponents and proponents of wind power on behalf of the regional planning association, Peter Wirth and Markus Leibenath obtained direct insights into the discussions [29].

In a second stage of data collection in 2018 and the beginning of 2019, the authors focussed on the possible impact of local anti-wind power protests between 2011 and
2013. To this end they conducted six semi-structured interviews with actors involved in the planning and political processes in the period under investigation. These include two representatives of the regional planning association of Upper Elbe/East Ore Mountains, namely the head of the planning bureau as well as the chairman of the association, who is also the head of an administrative district (Landrat) and a member of the Christian Democratic Party (CDU). Moreover, the authors interviewed an expert employed by the Green Party (Grüne), who were an opposition party in the Saxon parliament, as well as a former CDU member of parliament (and former state minister) acting as an environment and landscape expert. Interviews were also conducted with a civil servant of the CDU-led Saxon Environmental Ministry, two civil servants of the CDU-led Saxon Ministry of the Interior in the field of spatial planning as well as an expert of the Saxon Energy Agency, who in this case worked for the Saxon Economic Ministry responsible for energy policy (led by the FDP, the Liberal Democratic Party). Although he did not agree to an interview, the former CDU Prime Minister contributed some helpful written remarks. An interview with a senior FDP politician was arranged but could not be realised by the time of writing. Furthermore, comprehensive minutes of 12 debates in the Saxon parliament from the period September 2010 to May 2013 were analysed along with other documents. Finally, 21 additional articles from the newspaper Dresdner Neueste Nachrichten (October 2010 to September 2013) were collected and analysed.

\section{Results-the comprehensive storyline}

Following the causal-process tracing method, a comprehensive storyline is constructed to form the basis of analysis. This storyline refers to a "longer time through which the overall causal process evolves", conveying the bigger picture by focusing on structural factors [28, p. 111]. It shows the sequence of events in a vivid and detailed manner, thereby pinpointing "the development of potentially relevant causal conditions" [28, p. 111]. Regarding the storyline for the present case study, it should be noted that not only the opponents of wind power were active during the investigated time period. Also the proponents were involved, particularly the VEE Saxony (an association to promote the use of renewables). However, in view of the relatively weak voice and impact of proponents, the focus of this study can safely be placed on the protests of citizens' initiatives.

In the following we begin by sketching the political and institutional background, namely regarding the German state of Saxony, the specific regional planning association, as well as the institutional structures and actors making up the setting of the investigated case. Before attempting a comprehensive presentation of the political and planning process, we first give an overview of the policy change to 
be explained. Although the key period under investigation starts with the increased targets for renewables and ends with the scaling back of these targets, the analysis also encompasses the earlier disaster at Fukushima, which triggered Germany's phase out of nuclear energy, as well as the period directly following the reduction in targets.

\section{Saxony and the regional planning association in focus}

Saxony is a federal state of around four million inhabitants located in the southeast of Germany with borders to Poland and the Czech Republic (see Fig. 1). It has a mixed topography, featuring lowlands, hilly regions and the Ore Mountains. Three important framework conditions for wind power development in Saxony need to be mentioned from the outset:

- First, there is a sufficient natural potential to harness wind power as an energy source [30].

- Second, a study of all German states from 2012 showed the population of Saxony to have the lowest acceptance of landscape changes due to wind farms. Specifically, $58 \%$ of respondents expressed a negative opinion [31, p. 68].

- Third, there is a tradition of using lignite for power generation, particularly in the structurally lessfavoured area of Lusatia.
Saxony has four regional planning regions governed by statutory regional planning associations. In this study we consider the region of Upper Elbe Valley/East Ore Mountains (Oberes Elbtal/Osterzgebirge). There-in contrast to the other regions-the state's proposed increased renewables targets were very quickly broken down into designated areas for the siting of wind farms. This immediately provoked strong protests. The region encompasses the Saxon capital city, Dresden, as well as two largely rural administrative districts (Landkreise), namely Meißen and Saxon Switzerland/East Ore Mountains.

\section{Institutional structures and actors in Saxony-the setting} Figure 2 shows the identified institutional structures and actors in 2011-2013. The lines connecting the various boxes depict potential relationships between the respective organisations or actors. It should be noted that the federal government stipulates important laws such as the Renewable Energy Act (EEG), which provides feed-in tariffs for renewables, as well as the Federal Building Act (BauGB), which determines the requirements for building facilities outside cities and towns [32, 33]. At the same time, the individual German states enjoy their own particular competencies regarding energy and climate policy, e.g. regarding targets for renewables and the siting of wind farms. From 2009 to 2014 the Saxon government was formed by a coalition of the conservative

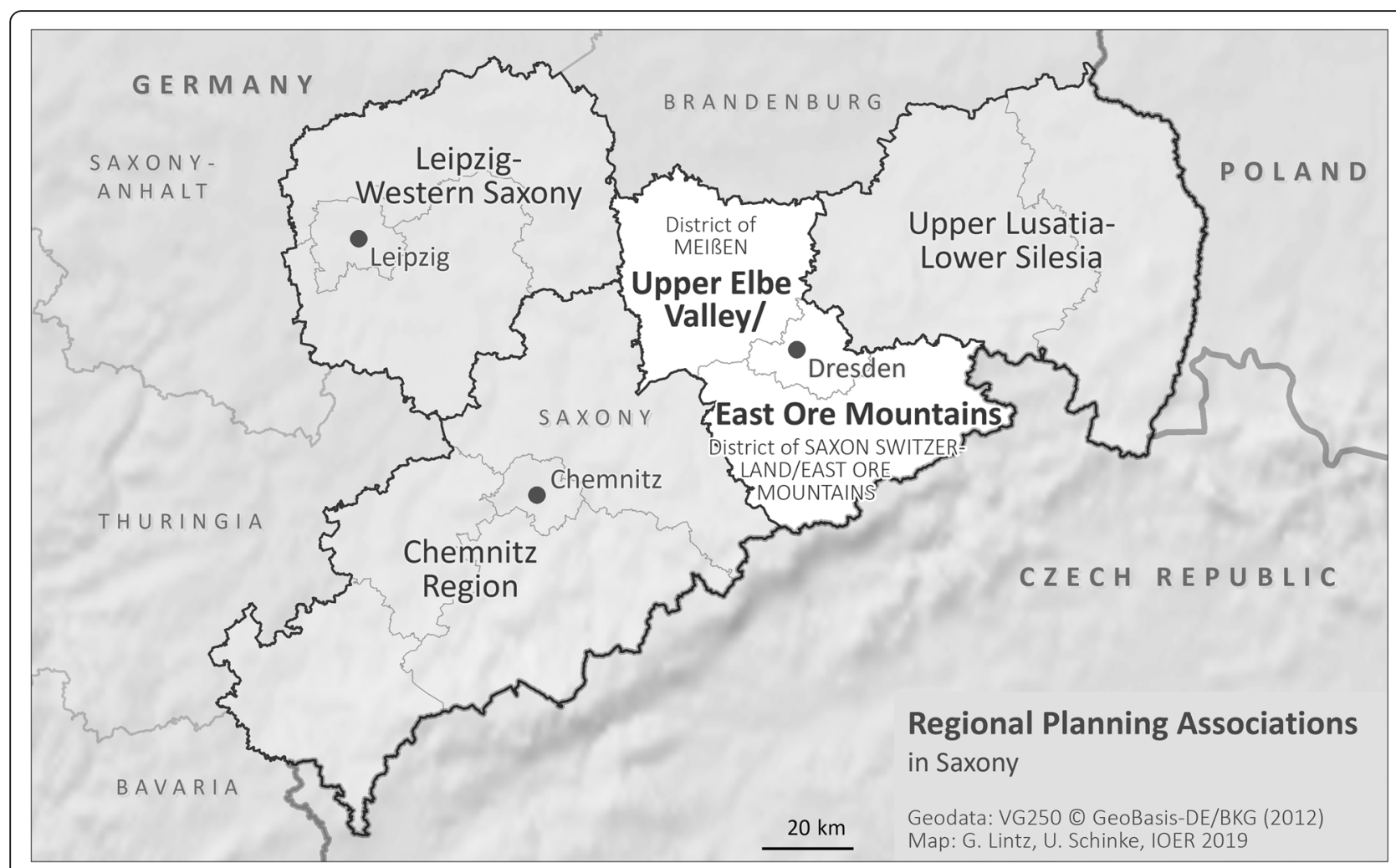

Fig. 1 Regional planning associations in Saxony 


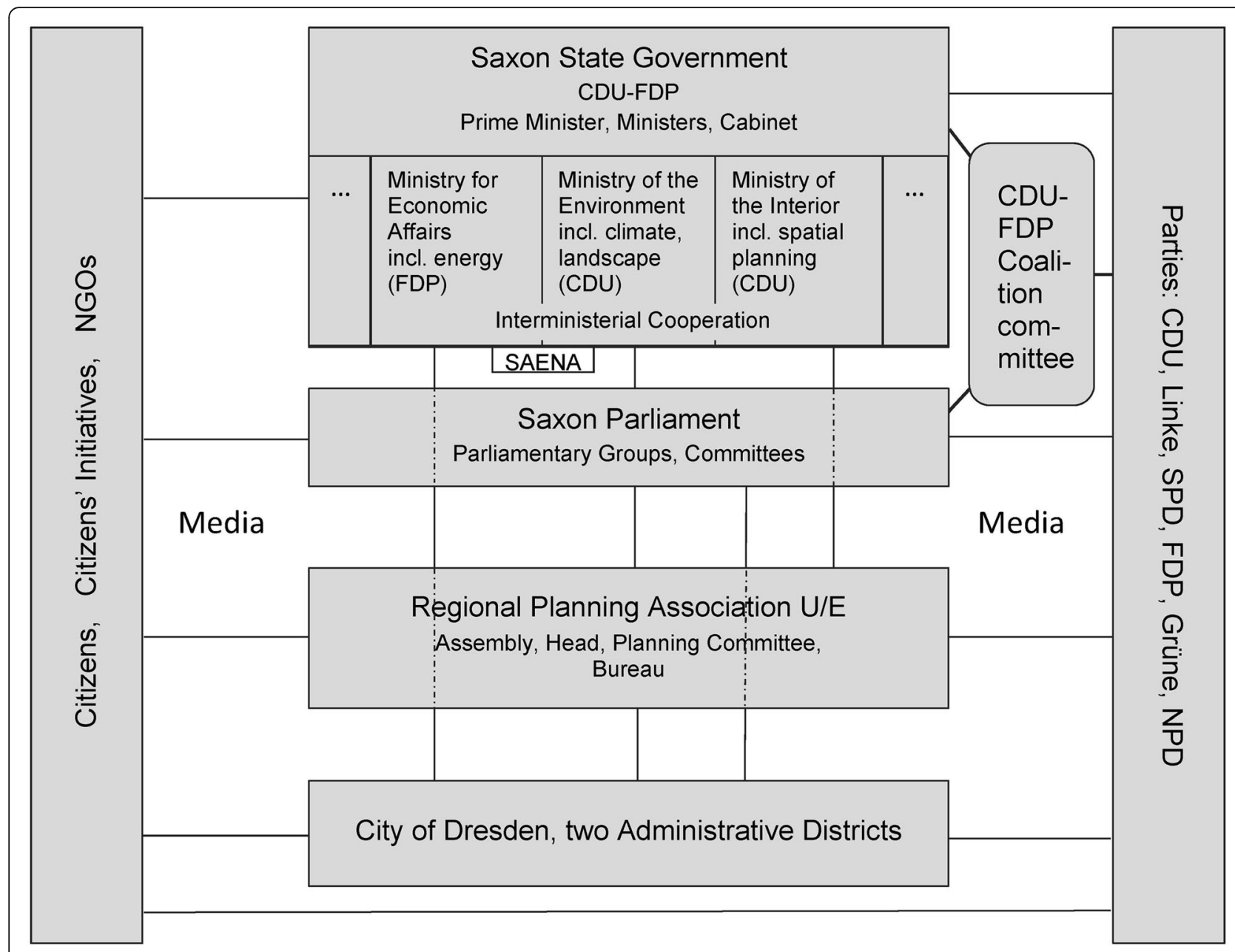

Fig. 2 Institutional structures and actors, 2011-2013 (own design)

Christian Democrats (CDU; $40.2 \%$ of the vote in state parliamentary elections), who have governed Saxony since the reunification in 1990, and the pro-business Liberal Democrats (FDP; $10 \%$ of the vote). While the FDP-led Ministry for Economic Affairs was in charge of energy policy, the CDU-led Ministry of the Environment dealt with climate policy and the CDU-led Ministry of the Interior was in charge of spatial planning at state level. Technical expertise on sustainable and innovative energy policy was concentrated in the Saxon Energy Agency (SAENA), which, in the context of policy on renewables, worked for the Saxon Ministry for Economic Affairs.

The most important decisions, particularly those on energy policy, were made by the coalition committee. This is a coordinative body aimed at resolving conflicts and which links the government, coalition parties and parliament. The committee members included, from the CDU, the Prime Minister (also head of the CDU in Saxony) and the head of the CDU parliamentary group as well as, from the FDP, the Minister of Economic Affairs (also Deputy Prime Minister) and the head of the Saxon FDP (also head of the FDP parliamentary party). While the Saxon parliament intensively discussed all pertinent matters on renewables, it did not take any binding decision on the mentioned policies.

The decision-making body of the regional planning association of Upper Elbe Valley/East Ore Mountains (U/E) is an assembly consisting of elected delegates from the parliaments of the city of Dresden and the two administrative districts (Landkreise). The districts constitute the CDU's electoral base and are comprised of many smaller municipalities. The delegates to the assembly include the Lord Mayor of Dresden and the heads (Landräte) of the administrative districts, who are in close contact with their fellow CDU members in government, parliament and party. The planning association also has a chairman (a position held by the head of the administrative district of Saxon Switzerland/East Ore Mountains) and a planning committee. To meet its administrative functions, the planning association maintains a planning bureau staffed by professional planning officials.

Within the Saxon government, the setting of targets for renewables is basically the responsibility of the Ministry 
for Economic Affairs. It is important to note that the regional planning associations are charged with identifying and delineating the sites needed to meet these targets. The process- and content-related framework for the activities of the associations is, in turn, determined by the Ministry of the Interior through the Saxon Spatial Development Plan. The delineated sites, or as they are officially called, "suitable areas for wind energy" (Vorrangund Eignungsgebiete), are intended to gather together wind farms while preventing the construction of wind turbines elsewhere. The extreme left field in Fig. 2 represents the individual citizens, citizens' initiatives and NGOs who protested against wind power sites in the period in question, while the extreme right field lists the parliamentary parties.

\section{Ambitious targets are scaled back-the phenomenon to be explained}

The paper aims to shed light on the role of local protests in the scaling back of ambitious targets for the expansion of renewables. Table 1 gives an overview of how exactly these targets were revised. In May 2011, following the Fukushima disaster and within the context of Germany's Energiewende, the Saxon government raised its 10-yeartarget for the expansion of renewables from 24\% (set in 2009) to $33 \%$ of gross electricity consumption [35, 36]. Accordingly, in October 2011 the detailed Saxon draft Energy and Climate Programme [37] increased the target for electricity generated by wind power from 2530 to 3500 GWh per annum. In March 2013 the government then set a more modest target: The adopted programme [38] specified a share of only $28 \%$ renewables in the electricity mix, with a disproportionate decrease of wind energy to a mere $2200 \mathrm{GWh}$ per annum. Table 1 also indicates the actual share of renewables in gross electricity consumption for each year in question.

\section{Fukushima and the increased wind expansion targets at state level}

In order to understand the relevant processes, it is important to consider the situation before May 2011, when targets for renewables were increased (see Table 1). Wind power had not been a major topic in Saxony before the
Fukushima disaster of March 2011. Certainly, we can identify an advocacy coalition for wind power that included private local investors, some municipalities, wind farm developers (associated in the VEE Saxony) and two political parties, the Greens and the Left (Linke). However, the broad and strongly dominant advocacy coalition consisting of the two governing parties, the CDU and the FDP, the important Saxon energy industry (based on mining and burning lignite) and existing anti-wind power initiatives made sure that wind power developed at a slow pace. This also reflected public opinion of wind power at the time, which was largely sceptical.

The development of renewables can be traced back to the 1970s [39], and the goal of a German Energiewende already played an important role at the end of the 1990s and the first half of the 2000s. Yet, the Fukushima disaster proved to be a major turning point in the government's energy policy. When Chancellor Angela Merkel reversed her positive view of nuclear energy, she was supported by overwhelming public opinion favouring a decisive shift away from this source of power [40, p. 6]. Appreciating the need to curb carbon emissions from fossil fuel-fired power stations, there was also a widespread effort to improve the efficiency of energy use and to boost the use of renewable energies. Parliamentary elections in the German state of Baden-Württemberg at the end of March saw the Green Party, a long-time opponent of nuclear energy, increase their share of the vote by around 12 percentage points whilst the CDU and the FDP each lost around 5 percentage points. The federal government was about to adopt concrete targets for the expansion of renewables when the Saxon Government, along with many other German states, positioned itself on the issue. In May 2011 the Prime Minister of Saxony (CDU) announced in a government declaration to parliament the new, more ambitious target of a 33\% share of renewables in gross electricity consumption to be achieved by 2021 .

This announcement and the following parliamentary debate named almost all the arguments expressed in subsequent years on this controversial issue such as the likelihood of higher energy prices for consumers (due to legally binding subsidies for renewables to be paid for by the energy sector), the question of a reliable power

Table 1 Development of 10-year targets for wind energy expansion

\begin{tabular}{llll}
\hline 10-year targets & $\begin{array}{l}2009 \\
\text { Action programme (also } \\
\text { coalition agreement) }\end{array}$ & $\begin{array}{l}\text { October 2011 } \\
\text { Draft Energy and Climate Programme } \\
\text { (according to government declaration } \\
\text { of May 2011) }\end{array}$ & $\begin{array}{l}\text { March } 2013 \\
\text { Climate Programme }\end{array}$ \\
\hline Target: share of renewables in gross electricity consumption & $24 \%$ & $33 \%$ & $28 \%$ \\
Actual value in that year & $13 \%$ & $16 \%$ & $18 \%$ \\
Target: Wind energy, GWh/a & 2530 & 3500 & 2200 \\
Actual value in that year & 1363 & 1653 & 1559 \\
\hline
\end{tabular}


supply, the role of Saxon lignite, the impairment of landscapes and the public's acceptance of wind farms. At the end of the debate, the parliamentary CDU-FDP majority called for an energy supply that is safe, reliable, affordable and environmentally friendly. Although the decision to set the new target was rather spontaneous and did not involve a wide range of actors, the government very likely drew on a study by the Saxon Energy Agency (SAENA), which was already charged with reviewing Saxony's energy and climate policy [41]. It has been suggested that the Saxon government determined its target of $33 \%$ by subtracting the potential for offshore wind power (which is not available in Saxony) from the federal government's target of 38\% [41].

Based on the 33\% target, the Ministries of Economic Affairs and the Environment, the SAENA as well as the Ministry of the Interior developed a draft Energy and Climate Programme. After this draft was presented in October 2011, an official consultation process was launched involving so-called "public-interest bodies" (Träger öffentlicher Belange) but excluding the general public.

In November 2011 the Saxon parliament had the opportunity to discuss the draft of the Energy and Climate Programme [42]. Although both parties had been in favour of a slow expansion of renewables, this debate confirmed the more positive stance of the CDU towards the Energiewende than the FDP. At the same time, as in the previous parliamentary debate, the CDU and the FDP were forced to defend their targets against the higher figures set by the federal government, while the opposition parties proposed even more ambitious targets. The parties in power highlighted the need to reduce carbon emissions through the use of renewable energy sources; nevertheless, they also reiterated their demands that the energy policy include Saxon lignite for power generation, ensure a reliable supply of power, remain affordable for businesses or private households and be environmentally friendly. Regarding this latter consideration, the CDU and the FDP repeatedly mentioned the detrimental impact on the landscape and the need to foster acceptance of renewables, thereby revealing some awareness of these problems. The Minister for Economic Affairs voiced the expectation that the Energy and Climate Programme would finally be adopted in the spring of 2012 (in the end it took one year longer).

In December 2011, along with other associations, the regional planning association under investigation filed its official statements regarding the draft programme, which it viewed as a "significant challenge" and "very ambitious" [43]. Drawing on their own experience of protests against planned wind farm sites, the association members were acutely aware of the difficulty of implementing such targets [44]. There was no further formal involvement of the regional planning association in the development of the Energy and Climate Programme beyond this statement.
On 26 January 2012 another debate was held in parliament [45], this time initiated by the Left Party, who demanded a higher target for renewables of $40 \%$, while the Greens stated that this would be insufficient to stop global warming.

\section{Rapid designation of draft sites for wind farms to meet the new targets}

The special role of the regional planning association under investigation arises from the fact that when the targets of $33 \%$ and $3500 \mathrm{GWh} / \mathrm{a}$ were announced, it was-unlike in the other Saxon regions [46, 47]-in the process of designating locations for wind farms [44]. Interestingly, the Ministry of the Interior (the superordinate authority) refused to approve the part of the new general regional spatial development plan (submitted in 2008) dealing with wind power: The association had intentionally designated insufficient space for wind farms to meet the then rather low state targets for the expansion in wind power [46]. In an extra process, the association had to revise this part of the plan and was about to increase the areas for wind farms according to the 2009 state energy targets for Saxony. In September 2010 a draft siting plan was even confirmed, and the formal participation process was started [44, 48].

However, after the publication of the draft Saxon Energy and Climate Programme in October 2011, the planning region quickly decided to increase the number of designated draft sites for wind farms to accommodate its share of the $3500 \mathrm{GWh} / \mathrm{a}$ target [46]. For this, the planning association again considered a wide range of criteria: some sites were excluded, for example, because of their proximity to Dresden airport or because they were too close to settlements. Landscape and nature conservation areas were also rejected as potential wind farm sites. Aesthetic aspects of landscape development were also taken into account. Figure 3 shows the final draft map of old and new areas for wind farms drawn up in February 2012. The simple circles indicate the 12 suitable sites already designated and approved in the 2003 wind power plan, which at the time still formed the valid basis for regional planning. The concentric circles indicate those 14 sites which were introduced in the map of February 2012.

\section{Local initiatives as a possible causal factor-actors, concerns, forms of action}

As soon as the planning association produced a preliminary draft of those sites chosen to contribute the region's share of the $3500 \mathrm{GWh} / \mathrm{a}$ target of October 2011, they informed the newly affected towns and villages of the 14 additional sites [49]. At the same time wind power investors were already undertaking intensive land surveys in the prospective areas. Local citizens were thus in no doubt that decisions on suitable locations for wind 


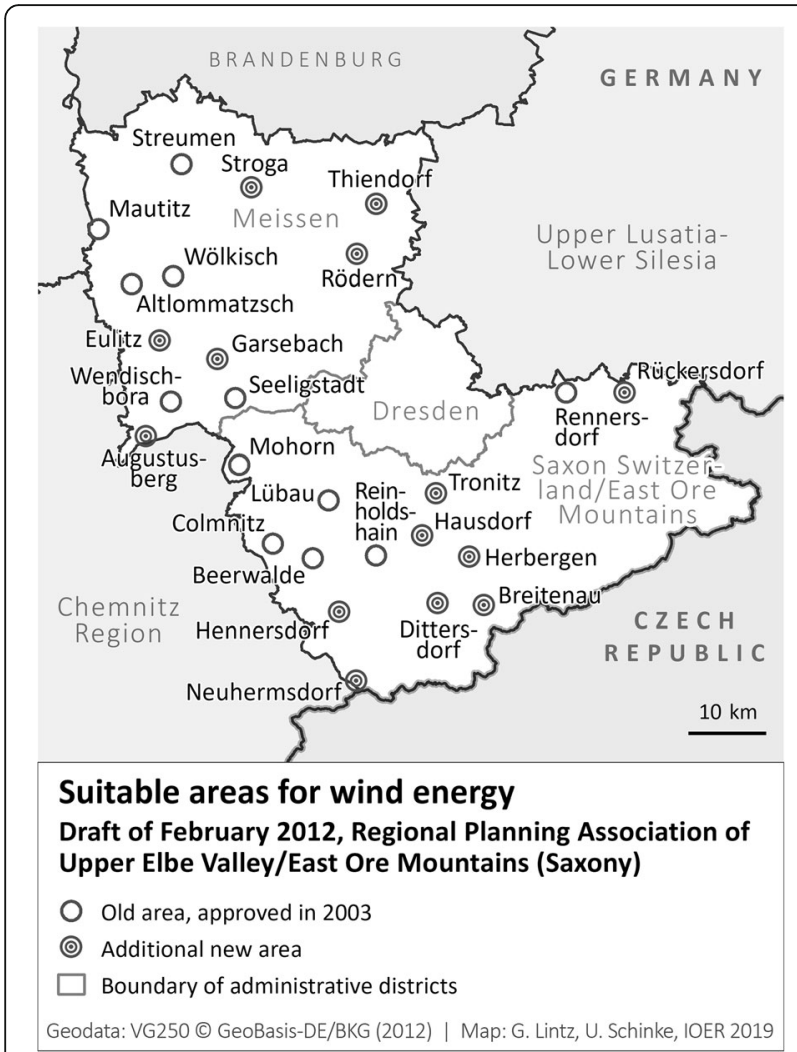

Fig. 3 Old and additional suitable areas as of February 2012

energy would very likely be followed by construction work.

While some anti-wind power initiatives existed in the planning region before 2012, the protest movement started to snowball at the beginning of that year. New protest initiatives against wind power were quickly established: The most vigorous of these came from the north of the Meißen District, around the sites of Stroga and Rödern. In the latter case, wind turbines were planned to be built in a forest, a form of development that had previously been prohibited. Through our analysis of 301 newspaper articles, we could identify 14 anti-wind initiatives in the planning region under investigation with 23 active citizens mentioned by name. The most vigorous initiatives were those founded or led by particularly skilled actors, e.g. an entrepreneur, who also funded some campaign activities [50], a retired forest engineer and a retired manager.

The analysis of interviews, press articles and other documents clearly reveals the demands of these initiatives, namely that sites designated for wind farms in the draft map be withdrawn, significantly curtailed or moved further away from settlements. The activists voiced a wide range of concerns against the planned areas including the potential negative impact on flora and fauna, particularly birds and bats, as well as infrasound pollution. However, the most important fear was the impact on the landscape.
This was very often expressed directly, for instance by claiming that wind farms destroy the landscape or, adopting the image of turbines as asparagus stalks, describing the Verspargelung (literally, the "asparagus-isation") of the landscape. Many people simply wanted their accustomed landscapes to be protected. There was also a strong demand for the establishment of a large minimum distance between the wind turbines and settlements. Against the backdrop of the European Landscape Convention, this can be interpreted as a call for a minimal impact on the landscape as perceived by local residents. As described by one journalist: "People don't want to lose their undisturbed view over the forests and fields" [51].

There are two more considerations arising from the local context which perhaps made the protests more emotional. Firstly, the initiatives complained that wind farms placed an unequal burden on people in rural areas, which were already neglected and lagging behind. This was in stark contrast to the city of Dresden, where no wind turbines were planned because of the population density and landscape conservation areas [46]. Secondly, protesters were reminded of an earlier fierce struggle about sewage treatment plants and sewage fees, which led to the founding of new independent party groups $[47,52]$.

While intensively gathering information about the impact of wind turbines, the initiatives adopted many forms of action such as creative demonstrations, signed petitions, the dissemination of leaflets, posters, visualisations, talks to politicians and journalists, letters to the editor and the setting up of websites. In some cases, protestors did not shy from personal insult: The head of the planning association was denigrated as a "lackey" and a "flunky" [47]. Moreover, he was criticised as not being on the side of the people. The various forms of actions were largely aimed by the initiatives or their members at mobilising support, explaining their position, posing their demands as well as threatening decision-makers with unpleasant repercussions such as lawsuits or lost votes in upcoming elections in May 2014 (municipalities) and September 2014 (state parliament).

\section{From protests to impact-a detailed chronology of the key period}

Here we provide a detailed chronology of this key period from February 2012 to March 2013, which encompassed the emerging protests and the scaling back of the targets for renewables. In this chronology, which is difficult to break down into separate phases, we note the dense flow of events unfolding across several politico-administrative levels and within various interlinked contexts such as the Saxon energy and climate policy as well as spatial planning at regional and state level. Between March 2012 and April 2013, no fewer than 301 articles related to wind power 
were published in just one newspaper (Sächsische Zeitung).

\section{Early confrontations}

In our view, the first significant event of the key period (from the disclosure of the planned expansion of wind power to the reduction of state targets for renewables) took place at the level of regional planning. This was an information meeting in February 2012, vividly remembered by three interviewees, which was held in a municipality close to the Rödern site [46, 50, 52, 53]. The affected municipality invited the regional planning bureau to present and explain its draft siting plans. Around 150 local citizens who attended the event expressed their anger about the planned development of wind farms.

While the public was not included in the consultation process for the important draft of the Saxon Energy and Climate Programme, some initiatives made use of official participatory processes to voice their concerns during the development of the Saxon Spatial Development Plan. As previously mentioned, this plan determines the framework by which the regional planning associations develop their siting plans for wind farms, for instance according to the principle of wind farm clustering. On 6 March, a public discussion on the draft plan (attended by the authors) was held in the town of Meißen [54]. Following the presentation of the first draft by the Minister of the Interior, the northern initiatives voiced various demands, including bigger distances to local settlements. Citizens also vigorously complained that wind power investors were already signing preliminary contracts with land owners. A meeting of several initiatives with the Minister of the Interior followed in March 2012. On 25 March a lengthy article strongly supportive of the protest movement was published in a tabloid newspaper [55], an opinion echoed by at least one journalist at another newspaper [46].

On 28 March, again at the regional level, the assembly of the regional planning association under investigation held a decisive meeting at which the draft plan for wind power areas based on the 2011 renewables targets (cf. Fig. 3) was to be officially confirmed, thereafter to enter the formal hearing and participation phase [56]. Around 180 people attended the event along with a representative of the Ministry of the Interior. A television crew was on hand to report on the proceedings. The protesters were very well prepared for the meeting, making their presence felt by holding up posters and rotating umbrellas coloured black and white to represent wind turbines. Eleven representatives of five antiwind initiatives were given the opportunity to speak. In a significant step, the planning association decided to postpone confirming the draft plan because of the protest demonstration and the wide-ranging concerns that were so forcefully expressed. The initiatives were given the opportunity to submit their concerns in writing. Moreover, visits to proposed sites were agreed in order to create a better basis for planning decisions. This proved to be a turning point for the planning association, which started to doubt the viability of the new targets for renewables and wind power specified in the draft Energy and Climate Programme. The association members even expressed the wish to end their "predisposed obedience towards the state government" [46]. Instead they wanted to ensure that their plans were drawn up on the basis of the final targets.

\section{Broadening and intensification of campaign}

Subsequently, the citizens' initiatives significantly broadened and intensified their campaign, systematically approaching relevant political actors at all politicoadministrative levels, particularly those with connections to their local areas. On 20 April one of the initiatives met with a member of parliament (and former Saxon Minister of Justice) of the CDU district organisation of Meißen. On 16 April, at the local level, the council and administration of the town of Großenhain, which is close to the Stroga site, presented their clear and vehement rejection of wind power. This is particularly striking as the mayor of the town had initially promised to support wind power investors. On 26 April another initiative met with the mayor of an affected municipality. These are examples of lobbying at the local level, a phenomenon rarely reported in the press. On 27 April one of the initiatives used the opportunity of a grand opening of a new factory attended by the Prime Minister of Saxony and the German Minister of Defence (a fellow-CDU member who lives in the district of Meißen) to demonstrate against wind power [57]. On 3 May seven Saxon initiatives formed a network in order to coordinate and jointly carry out their actions and measures [58].

Only a few days later, on 8 May, the first of the promised inspections by the regional planning association took place in the north of the planning region. This and the following inspection were again exploited by the initiatives to express their disapproval of the plans in spectacular fashion when gas-filled balloons were floated at a height of $200 \mathrm{~m}$ in order to illustrate the size of potential wind turbines [51, 59]. Moreover, the head of the district of Meißen (CDU) was handed a petition with 2400 signatures. The inspection was also attended by the chairman of the regional planning association and several delegates of the association along with citizens and local politicians.

\section{The recognition of a mistake; increased networking among initiatives}

Shortly thereafter, the development of the Saxon Spatial Development Plan once again became a catalyst for debate. On 24 May a parliamentary committee of the interior convened an initial hearing of experts to discuss the draft plan [60]. The issues dealt with included the need for land to site wind farms, the dynamic link between the Energy and 
Climate Programme and the Saxon Spatial Development Plan, and problems of acceptance as well as legal questions regarding the role of landscape concerns in spatial planning arbitration. Interestingly, one expert for environmental policy (a former CDU member of parliament and Minister of Culture) pointed out that additional wind farms would contribute to the destruction of landscapes, a prospect which was already leading to massive local protests in Saxony. Most importantly, he openly stated that a mistake had been made: the expanded targets for renewables and wind power in the draft of the Energy and Climate Programme had been determined without examining the concrete spatial situation in Saxony. While that was largely true, civil servants dealing with spatial planning in the Ministry of the Interior had indeed made some efforts to highlight the significant spatial impact of producing $3500 \mathrm{GWh} / \mathrm{a}$ of wind power [61]. Recognising the conflict between energy and climate policy, on the one hand, and spatial planning, on the other, the parliament committee of the interior demanded better coordination between these sectors.

In order to improve the basis for decision-making, the regional planning association organised a field trip to a wind farm in the vicinity of the Bavarian city of Hof. The field trip, which took place on 29 May, was also attended by members of the citizens' initiatives. From May to June, members of an initiative were in touch with another member of the Saxon government, namely the Minister of Social Affairs. In particular, they sent her a dossier on the health risks of wind power, hoping to win a further advocate to their cause. In June 2012 several initiatives took the significant step of expanding their network by founding a Saxon branch of the Bundesverband Landschaftsschutz, a nationwide association for landscape protection. This enabled the initiatives to take advantage of the association's support for lobbying against wind farms. The Saxon organisation was headed by a strongly committed activist based in the Ore Mountains, specifically in an administrative district adjacent to the planning region. Also in June 2012 the planning association stated that all plans regarding wind power would now depend on the Energy and Climate Programme, which had still not been adopted [59]. This confirmed its new policy of "wait and see".

\section{The FDP distances itself from its shared position with the $C D U$}

The FDP had already made their scepticism of wind power clear in several parliamentary debates. Accompanied by a publicity blitz, the parliamentary group now launched a series of three large public conferences in Dresden aimed at criticising an overly ambitious environmental policy and, in particular, climate mitigation policies. Doubts about the man-made nature of climate change were voiced at the first of these, called the "Alternative Climate Conference", held on 30 June [62].

On 12 July two important debates took place in the Saxon Parliament [63]. The first, initiated by the CDU and FDP, dealt with the costs of energy policy. While the CDU stressed that the avoidance of higher costs should be at the heart of energy policy, one FDP member of parliament rebuffed the coalition partner, bluntly demanding a change in Saxony's energy policy and expressing his view that the Energiewende is like a party quickly followed by a hangover. He saw the energy transition as rushed, potentially causing the destruction of the beautiful Saxon countryside. One politician of the Green Party noted that the CDU-FDP coalitions at the national and Saxon level were being forced to implement the Energiewende even though they basically disagreed with it. In addition, the debate also addressed the anti-wind initiatives and the Saxon Spatial Development Plan. The second debate of the day dealt explicitly with the Spatial Development Plan on the basis of the recommendations made by the parliament committee of the interior. After an exchange of well-rehearsed arguments, the parliament adopted the parliamentary committee's suggestion that the government should improve the coordination of energy and climate policy, on the one hand, and spatial planning, on the other. In particular, the spatial effects of the energy targets should be examined early in the process.

Five days later, on 17 July, the second of the promised inspections by the regional planning association took place in the East Ore Mountains, which lie in the south of the planning region. At the same time one initiative in the north was highly active: in mid-July members had a meeting with the Prime Minister at his constituency office, handing him a position paper and studies on the danger of infrasound. In the summer a meeting took place between an initiative and the regional planning association, represented by the chairman of the association and the head of the planning bureau [46]. In July the council of Großenhain passed a resolution against proposed wind power sites near the town.

A newspaper article from 22 August reported on the anti-wind power campaign of a member of the German parliament and head of the FDP constituency of the Meißen district [64]. In the article, which featured a large photograph of the parliamentarian, he roundly criticised the Energiewende while supporting the aim of landscape protection. It is important to note that the Saxon Energy Agency (SAENA) was asked in August 2012 by the FDP Ministry for Economic Affairs to calculate alternatives to the $33 \%$ renewables target, namely a $30 \%$ or even $25 \%$ share of renewables in gross electricity consumption [41]. This is an early sign of concrete steps to scale back the ambitious targets for renewables. On 20 September the regional planning association held 
another assembly, attended by 100 citizens, which again gave representatives of the initiatives a chance to voice their concerns. In this period the spatial planning process was becoming bogged down due to uncertainty regarding the targets for renewables, which had still to be set. On 17 October the governing parties initiated another parliamentary debate on the explosion in costs caused by the Energiewende, and especially the EEG, the federal law to foster renewables [65]. Outlining the government's position, the Prime Minister clearly restated the primary goal of maintaining affordable energy prices. The citizens' initiatives continued their work: on 18 October one group submitted a signed petition in support of their demands to the president of the Saxon Parliament and other politicians.

\section{Rising tensions within the government; targets begin to crumble}

Tensions began to rise between the two coalition partners after the decision about the Energy and Climate Programme was postponed several times. On 30 October a newspaper published an article on the leader of Saxony's FDP, who was also the leader of the FDP parliamentary group [66]. Alongside the FDP Minister for Economic Affairs, he can be described as the key actor within the FDP. Specifically, he had initiated the mentioned FDP conferences and stated that the three FDP ministers in cabinet had agreed a $30 \%$ target for renewables. However, the article also mentioned his support for a further reduction in targets to $25 \%$ and his intention to raise this issue in the coalition committee. Moreover, he stated that he would go on fighting the expansion of wind energy in order to protect Saxony's cultural landscape, prevent the development of wind farms in touristic areas and ensure larger distances between wind farms and settlements.

On the same day the secretary general of the CDU, commenting on the struggle between the two governing parties, defended his party's actions against the FDP [67]. Now it seems that the CDU also arrived at a decisive turning point: The secretary general confirmed that the CDU was in favour of reducing the designated areas for wind power and had already reached an agreement in cabinet to cut the target for renewables to $30 \%$. Further, he criticised the FDP for its inconsistency in view of its new demand for a reduction to $25 \%$. Meanwhile the FDP was reaching out to the protest initiatives [52]. The party invited local protest groups to hold a joint conference on 13 November [68].

The regional planning association held another assembly on 19 November. However, still no progress could be made on wind power planning due to the lack of final energy targets for the Energy and Climate Programme. One journalist published a government leak that a proposed site would be withdrawn and a second site scaled back [69] while another reported that the planning association was losing patience [70]. Reflecting this mood, the head of the association wrote a letter to the Prime Minister demanding a quick decision on the targets for the programme [71]. The same newspaper article reported that the coalition partners in the government were struggling to agree on targets for the share of renewables in energy consumption, mentioning figures of $35 \%, 30 \%$ or $25 \%$. On 1 December the FDP parliamentary group held their second public "Alternative Energy Conference" in Dresden. A summary and video of the conference were posted on the website of an anti-wind initiative [72].

At the initiative of the Green Party, the parliament discussed Saxony's climate policy on 14 December [73]. This heated debate revealed the hardening positions on this matter, with the comments of some parliamentarians verging on personal insults. One member of the Green Party stated his belief that the government was about to quietly and secretly lower the $33 \%$ target. He also criticised the actions of members of both governing parties with responsibility for energy policy who were (already) promising reductions in the expansion targets for renewables to the citizens' initiatives. The Left Party also criticised the FDP for holding their "Alternative Conferences" while praising the CDU for accepting that climate change is man-made. One member of the FDP defended his party's position and, highlighting the rise in electricity prices and the need for better coordination in Germany and Europe, demanded that the expansion target for renewables be reduced to $25 \%$.

Following this period of intense argument, the regional planning association held a press workshop on 23 January 2013 to clear up possible misunderstandings regarding the complex matter of the siting of wind farms and released a corresponding press statement [74]. On 28 February the committee of the interior of the Saxon parliament held a second hearing on the revised draft of the Saxon Spatial Development Plan [75]. Initiated by the FDP, the head of the Saxon sub-organisation of the nationwide anti-wind association for landscape protection was given an opportunity to speak. He called for a minimum distance between wind farms and settlements of $2000 \mathrm{~m}$ or (alternatively) ten times the height of wind turbines, a demand which would certainly prevent the construction of any new wind farms in Saxony. The representative of the Saxon administrative districts (Landkreistag) highlighted the fact that the regional planning associations, caught between the lobby groups of the wind farm investors and local anti-wind initiatives, were being insufficiently backed by the government. A few days later, on 2 March, the FDP member of the German Bundestag pointed out that the proposed areas for wind power would hinder the work of the meteorological 
service. However, the regional planning association suggested that this argument was unlikely to have much impact.

\section{Negotiations between the camps}

Things then heated up within the Saxon governmental coalition. On 7 March a prominent newspaper article highlighted the fight between the two coalition parties regarding energy and climate policy, a topic deemed relevant for the upcoming elections [76]. The article stated that the government was indeed about to reduce the 33\% expansion target for renewables. As already stated in the newspaper article of 30 November 2012, the conflicting positions were a reduction to $30 \%$ as agreed by the cabinet and a reduction to $25 \%$ as demanded by the Saxon FDP and the FDP parliamentary group, both represented by the mentioned key FDP actor. He had brought this up at a coalition committee meeting which, according to one journalist (drawing on government circles), had taken place a few days before. The reporter assumed that only some final discussions were now needed with the parliamentary groups and between the ministries involved. Another important source claimed that the coalition committee had agreed to a reduction to $28 \%$ in order to better protect touristic areas and forests [77].

Finally, on 12 March, in line with the coalition committee's resolution, the cabinet took the official decision to set a target of $28 \%$, presenting the adopted Energy and Climate Programme at a press conference [38]. As already described, the final programme not only reduced the expansion target for renewables by 5 percentage points, but also disproportionately reduced the contribution of wind power from 3500 to $2200 \mathrm{GWh} / \mathrm{a}$. An informal hand-out distributed at the press conference stated that the reduction was the result of arbitration within the framework of the hearing and coordination procedures. The intention was to produce more than half of the planned $2200 \mathrm{GWh} / \mathrm{a}$ by upgrading existing turbines. Furthermore, the programme stressed that local acceptance and sufficient distances to settlements should have priority in the regional planning of wind farms. Clearly, this accorded with the demands of the opponents of wind power. While the conflicts did not vanish entirely, the situation calmed down [46].

\section{Subsequent events-the government tries to curb wind power further}

In order to give a full picture of the development in wind power planning, we now outline the main events of the subsequent period. The state's framework conditions for regional wind power planning were finalised on 12 July 2013 (four months after the decision to lower targets) with the adoption of the Saxon Spatial Development Plan [78]. Alongside the exclusion of forests as sites for wind turbines, the plan took up the two criteria for area selection already stipulated in the Energy and Climate Programme, namely local acceptance and a sufficient distance to settlements. In a supplementary decree, the Minister of the Interior and the Minister responsible for energy specified a standard distance of $1000 \mathrm{~m}$. The regional planning association voiced major criticisms of these two criteria [30, 79-81]. Keen to adopt a spatial plan which could not be rejected by the state government or the courts, it pointed out the illegality of considering local acceptance in the siting of wind farms. Moreover, the association claimed that a minimum distance of $1000 \mathrm{~m}$ would make it almost impossible to find suitable sites for wind turbines in the densely populated state of Saxony. As one journalist put it: "While the state government demands the expansion of renewables, at the same time it erects new hurdles" [79].

While the revision of the regional wind power siting plan was still ongoing and the deadline for updating the general regional spatial plan came closer, the regional planning association decided in September 2013 to end the separate planning of wind power and instead to integrate it into the general updating of regional planning [82]. It is worth mentioning that in both the general updating of the regional plan and the development of a new Energy and Climate Programme, additional participatory elements were drawn into the planning process. Finally, it should be noted that in the Saxon state parliamentary elections of 31 August 2014, the CDU lost a mere 0.8 percentage points of its previous share of the vote while the FDP lost 6.2 percentage points, taking them below the $5 \%$ hurdle and thus preventing them from returning to the state parliament.

\section{Discussion-tracing causality}

In the following we intend to establish and assess the causal chain leading from the local protests to the scaling back of the targets for renewables. The aim is to answer two questions simultaneously: whether there was indeed an influence and how this influence materialised. This analysis is embedded in the somewhat longer time period starting with the Fukushima disaster. While the described comprehensive storyline ("Results-the comprehensive storyline") already suggests that the protests had a significant influence, the process needs to be explicitly interpreted as a chain of causal events. Causality can only be determined by means of an in-depth investigation of the relevant causal steps [83, p. 184]. From the comprehensive storyline we can derive a condensed overview of the potential causal chain, structured into four steps. Figure 4 is an attempt to illustrate the causal chain. Here the rectangular boxes stand for causal conditions such as events and situations, while the rounded boxes offer explanations as to why an initiating condition leads to a certain outcome, 
with particular reference to the perceptions and motivations of the actors involved. The most significant rectangular boxes are in grey. The box on the bottom left represents the final outcome of the whole process. In the discussion, we first analyse causations 1-3 (rooted in the prior history) before investigating the key causation 4 .

\section{Prior history: from Fukushima to local protests in Saxony From Fukushima to increased Saxon draft targets for renewables (causation 1)}

The first question to be answered is why exactly the Saxon coalition government chose to set ambitious targets for renewables in the first place. The proposed rise in the share of renewables in gross electricity consumption and the corresponding increase in wind power generation are certainly significant jumps. In a debate, the former SPD Minister for Economic Affairs called the new target a "minor revolution" [42].

As described above, before Fukushima, the CDU and FDP lead a strongly dominant coalition advocating a slow increase in renewables and wind power in Saxony. Then came the Japanese nuclear disaster of March 2011, an event which (in line with the Advocacy Coalition Framework) can be interpreted as an external shock. This immediately transformed the thinking of the German Chancellor Angela Merkel (CDU), leading to the announcement of the phase out of nuclear energy, a major policy shift which was generally welcomed by the public. In the state election of Baden-Württemberg, the Green Party superseded the CDU as the leading coalition party. Germany's other states reacted swiftly to the tide of events, proclaiming their support for the Energiewende.

While we possess no information on any negotiations between the two government parties in this phase, only two months after the Fukushima disaster the coalition government (and so the two leading actors in the advocacy coalition for a slow expansion of renewables) changed its assessment of renewables. In line with a statement by an interviewee from the Green Party, it can be argued that the Saxon government had no choice but to introduce some measure in support of renewables [84]. Although there were no imminent elections (the municipal and state elections had only been held in May and August 2009), public and party expectations were high. And while it was the CDU Prime Minister who announced the increased targets, the coalition parties certainly backed the measures in parliament, at least initially. The decision to increase the targets for renewables can be described as rather spontaneous and without the participation of a broad range of actors. A revision of the Saxon energy and climate policy was already underway. Yet, given the CDU-FDP government's longstanding negative view of renewables, it can be concluded that it would not have increased the targets in 2011 to this extent without the influence of the Fukushima disaster and the Energiewende at the national level. Taken together, these interrelated events constitute a necessary and probably sufficient condition for the increase in targets. There seems to be no other plausible explanation for the significant increase in targets but the Fukushima disaster and its political impact at the national level.

\section{From increased targets for renewables to areas for wind turbines (causation 2)}

The adoption of an Energy and Climate Programme (ECP) is followed more or less automatically by the designation of potential wind power sites, since this is laid out in the state's Spatial Development Plan. One particular feature of the present case is that sites for wind farms were rapidly designated. This meant that protests arose during the drafting process of the ECP, thereby increasing their likely impact. In this respect, the main issue here is how to precisely explain this rapid preparation of a draft plan for designated wind power areas in accordance with the new expansion targets.

At the time of the presentation of the draft ECP, the regional planning association in question, in contrast to the other Saxon planning associations, was in the process of identifying suitable areas for wind energy (Vorrang- und Eignungsgebiete) for the previous wind power expansion targets. In this respect, it had to be decided immediately whether the association should designate sufficient land to meet the 3500-GWh target for wind energy, even though this was only a draft ECP. According to plausible information from the head of the planning bureau of the regional planning association, the association members were firmly convinced-also in view of the wider national trend-that the increased targets would not be subject to further revision [46]. Furthermore, the 33\% target for renewable energies had been announced in a government declaration. Instead of wasting time with the old targets, it was decided that all further planning considerations should take account of the new targets. Based on previous experience, some urgency was placed on developing a plan that would, if possible, stand up to the scrutiny of the Saxon planning authorities and courts $[46,47,53]$. This was important because rapid technical developments in the field of wind power had overtaken the previous basis for spatial wind power deployment in Saxony, which dated back to 2003 .

Under the requirements of the Saxon Spatial Development Plan, the drafting of a new energy and climate concept was both a necessary and sufficient condition for the selection of new sites for wind turbines. However, the rapid reaction of the regional planning association presupposes the particular reasons described above (an ongoing planning process, a decision in favour of rapid adaptation), which can therefore be regarded as 


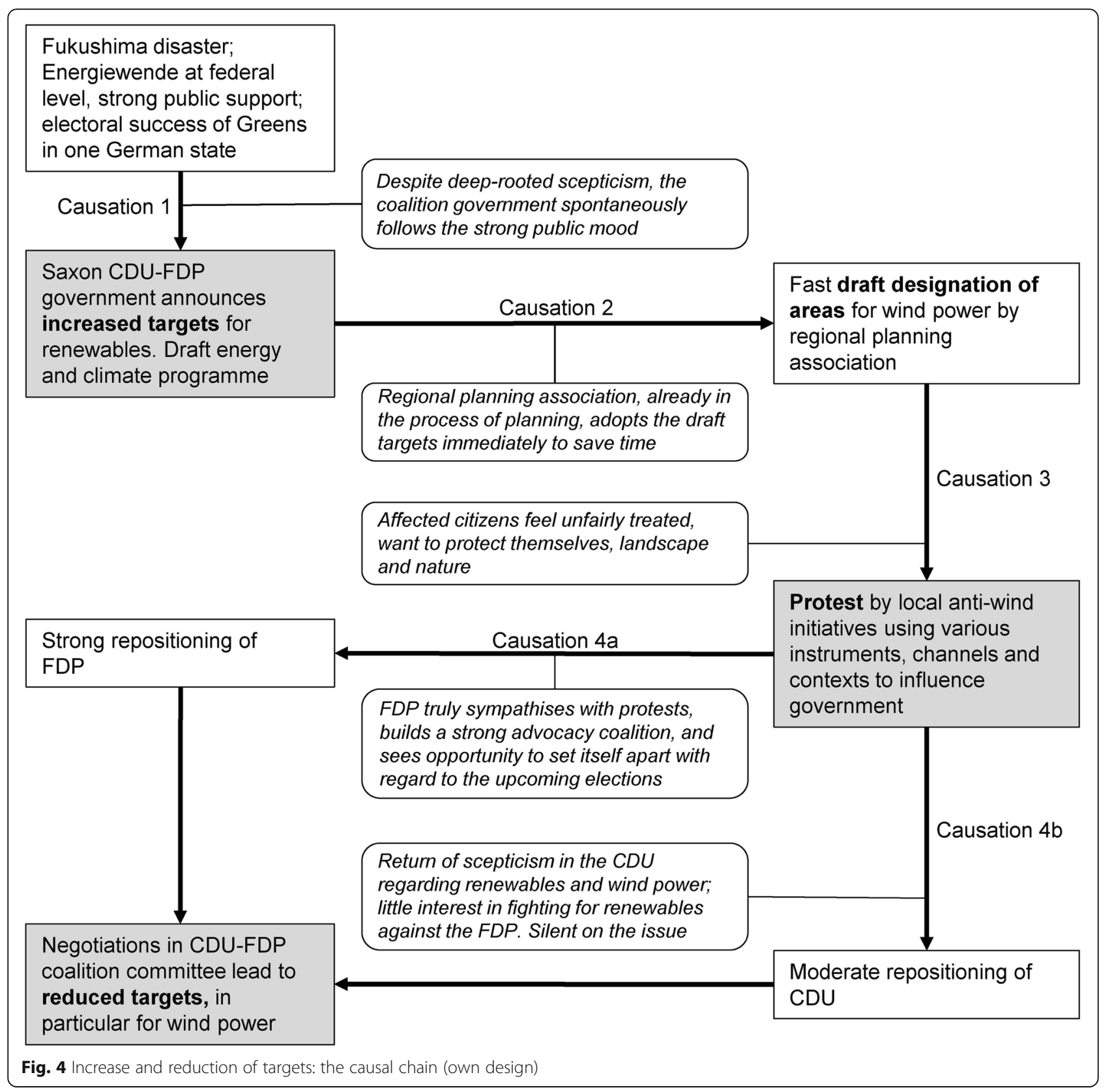

necessary but insufficient conditions. Hence, if the planning procedure for wind power had not also been underway, the ECP would not have been implemented in concrete areas until much later.

From areas for wind turbines to local protests (causation 3) The protests quickly increased significantly after the government's ten-year targets for renewables announced in May 2011 and specified in the draft of the Energy and Climate Programme of October 2011 were swiftly translated by the regional planning association into a draft plan of suitable areas for wind farms.
As the municipalities and citizens were informed at an early stage about the additional designated areas (in particular by the regional planning association and investors), they could be relatively certain that construction would indeed take place if these areas were subsequently given the green light. Their motivation was clear: many citizens were horrified by the plans, which in many respects ran entirely counter to their notions of good local development. Therefore, several new citizens' initiatives led by skilful leaders were established in opposition to wind power. Two of these stood out in terms of their expertise, their funding and coordinated efforts. The end result was a 
burgeoning protest movement with increasingly informed and organised initiatives.

No evidence, either from interviewees or the analysed documents, suggests that the protests were caused by anything other than the draft of the Saxon energy and climate programme and the subsequent breakdown of this draft by the regional planning association into areas for wind farms. However, the draft programme and the draft wind farm siting plan were a necessary but insufficient condition for effective protests. It was only in combination with the existence and commitment of skilful leaders that the protest movement was able to exert influence.

\section{Key step-from protests to the reduction of targets}

The following analysis of the key causation 4 starts by asking whether the protest activities were significant and did have the potential to impact the two governing parties. Then the reaction of the parties is discussed before we consider the negotiations between the parties (causation $4 a$ and $4 b$ ).

\section{Protests target government}

The chronology of the key year under investigation showed how the local initiatives launched a flurry of activities, systematically mobilising citizens and exploiting as many avenues as possible across various contexts and levels of the politico-administrative system to promote their message. For instance, they engaged with the local media and directly approached individual influential politicians at local, regional and state level. Local politicians were the first to lend their support to the protest movement (see also [46, 47]). The Saxon Prime Minister, several cabinet ministers and members of the Saxon Parliament were also directly lobbied by the citizens' initiatives. The initial focus of the work of local initiatives was on spatial planning at the regional level, where the areas for wind power were drafted. Protestors also targeted the process of elaborating and adopting the Saxon Spatial Development Plan, which was crucial for the designation of areas for wind power. In contrast, the Saxon Energy and Climate Programme could only be targeted indirectly.

The position of the initiatives was greatly strengthened by the support of the governing coalition FDP party, which fuelled public discussion by means of an intensive campaign. A new advocacy coalition against the ambitious renewables and wind power expansion targets emerged, one that enjoyed direct access to the Saxon parliament and the ministry in charge of energy policy. All in all, the protests can be regarded as significant, certainly with the potential to trigger a response by the Saxon government.

\section{Reaction of government parties to protests}

Given the nature of the protests, it is clear that the two parties forming the coalition government could not ignore the various critical impulses flowing through various channels and contexts, and were fully aware of the campaign against the proposed areas for wind power and the draft of the energy and climate programme. We can safely assume that intensive discussions took place within the two parties. For example, the chairman of the regional planning association, who also headed a member district and was a CDU party politician, reported that he had warned the CDU Prime Minister on several occasions that the protests could have a major negative impact on future election results [47].

An unusual dynamic ensued. As any decision to scale back the targets had to be negotiated within the governing coalition committee by CDU and FDP representatives, the reactions of the two coalition parties to the intensive local protests were crucial. How did the parties perceive the emerging protests and what was the motivation to react as they did?

Two important aspects of relevance to both parties have to be mentioned first. First, the increase in targets was directly linked to the Fukushima disaster (an external shock) and the ensuing emotional public discussion. And second, there was a strong continuity in the government's arguments in parliamentary debates regarding the importance of keeping down energy costs, maintaining a secure supply, exploiting Saxon lignite and protecting landscapes $[35,42,45,60,63,65,73,75,85-88]$. This suggests that the decision to increase the targets for renewables after Fukushima was not evidence of a fundamental shift in political conviction, but rather the result of public pressure and the sweep of events. This no doubt made it easier for the parties to subsequently revise their positions. At the same time, it should be remembered that both the Energy and Climate Programme and the designation of areas for wind power were still-at least formally-at the draft stage. This will also have made it easier to justify the change in policy.

\section{Strong repositioning of the FDP}

In addition to local initiatives, the FDP can clearly be seen as the driving force in Saxony and within the governing coalition against the expansion of wind power. This is confirmed by the discussed actions as well as by the clear and undisputed statements of interview partners and press articles. In particular, the head of the Saxon branch of the nationwide anti-wind association for landscape protection mentioned that the protest initiatives needed political partners at the state and federal levels, pointing out the key role played by the FDP parliamentary group in Saxony [89]. Most importantly, the FDP explicitly claimed success itself, particularly in having recognised the concerns of the 
anti-wind initiatives: one newspaper article detailing the obvious success of the protests in some regions quoted the FDP Minister for Economic Affairs, who explained that the government had reacted to public criticism of the likely destruction of the landscape [90].

Why did the FDP choose to fight to reverse the more ambitious policy for renewables laid down after the Fukushima disaster? In addition to the two abovementioned aspects, we can point out two highly plausible arguments that offer an explanation. First, the Saxon FDP primarily saw itself as the party of entrepreneurs and the economy. Holding the Ministry for Economic Affairs in the coalition government, the FDP was strongly opposed to subsidising renewables, viewing this as likely to raise energy costs for companies and jeopardise energy security. Moreover, the party in general, and in particular its long-standing leader, were energetic supporters of individual motorised transport, for instance arguing for the construction of a controversial bridge across the river Elbe in Dresden. In various respects, the FDP viewed the Green Party as its main political rival [91]. During general debates, FDP members even expressed doubts about the likely impact of human activities on the climate. In sum, there is little doubt that the FDP truly sympathised with the protest initiatives.

Second, municipal and state elections were to be held in May and August 2014. The fight against the ambitious targets for renewables was clearly seen as a good way to further sharpen the FDP's profile. Thus, the protests encouraged the FDP to fight against the trend towards renewables which emerged in the period after Fukushima. Heading the ministry in charge of energy policy, the FDP was in a very strong position. In the end, the FDP's position was that landscapes should in no case be sacrificed in this shift towards renewables, a policy seen as fundamentally flawed.

\section{Moderate repositioning of the $C D U$}

As the dominant party in the regional planning association and in the affected regions/districts, the Saxon CDU quickly came under fire from local initiatives. Nevertheless, the change in the party's attitude can be interpreted as rather hesitant and reactive. It distanced itself to a certain extent from its original goals, although not as clearly as the FDP. The following persuasive explanation can be given for this, in which at least four elements play a role.

The first of these concerns the basic attitude of the Saxon CDU towards the Energiewende. Although the party shared with the FDP the aims of ensuring a cheap, secure and environmentally friendly energy supply based on coal, nuclear energy and only supplementary renewables, it did not display such a deep-rooted scepticism of the entire Energiewende as its coalition partner. Of course, the Energiewende was a project initiated by Chancellor Merkel, head of the CDU at national level. Furthermore, in this period the Saxon CDU was in charge of the Ministry of the Environment, and thus responsible for fighting climate change. Second, as it was the CDU Prime Minister who officially announced the $33 \%$ target, any reduction in this ambitious goal could potentially damage his image.

Third, the decision of the FDP to use this topic to sharpen their profile for the upcoming elections against the CDU was significant. The CDU saw itself confronted by a growing advocacy coalition against the ambitious targets for renewables. On the one hand, this ruled out the option of getting the coalition government through this difficult situation by simply sticking to the targets and perhaps later pursuing these with little enthusiasm. On the other hand, the CDU did not see close alignment with the Energiewende as an attractive strategy by which to distinguish itself from the FDP.

Fourth, as pointed out by the chairman of the regional planning association (CDU, also head of a member district), there were already at least two other big topics for which the CDU was strongly criticised in public, namely the alleged underfinancing and understaffing of the police force as well as schools [47]. Therefore, according to the interviewee, the CDU wanted to get rid of the issue of renewables and wind power as an additional potentially damaging topic before the elections. Here it should be remembered that the local protests originated in CDU's rural strongholds. In the end, the CDU had to admit, at least internally, that they had underestimated the likely general and political costs, especially the public resistance to landscape change. As pointed out by a former CDU politician in a parliamentary hearing, the increased targets for renewables were fixed before anyone investigated whether sufficient space would be available for the additional wind farms.

The CDU obviously wanted to maintain a low profile regarding the topic of renewables. Neither the CDU environment minister nor the CDU as a party conducted much public relations work regarding the Energy and Climate Programme, or at least no details made their way to the newspapers. After the adoption of the programme, one energy expert of the CDU parliamentary group simply stated that Saxony was following its own path regarding energy and climate policy [92]. Neglecting to mention that it was the CDU who had initiated the original expansion targets for renewables, he pointed out that the clear reduction in targets would ensure that energy remained affordable and landscapes protected.

\section{Final negotiations within coalition government}

It is certainly possible that the two partners in the governmental coalition had already struggled over the expansion of renewables before the FDP openly turned against the 
CDU. In any case, under mounting time pressure, the struggle between the competing camps culminated in tense negotiations between cabinet ministers and, finally, within the coalition committee. According to the Advocacy Coalition Framework, these negotiations reflect the fourth path to policy change, here a reversal of a previous policy decision. Eventually the only active and strong advocacy coalition left was in favour of a major readjustment of the 2011 expanded targets for renewables. This was made up of the FDP, the citizens' initiatives which had thrived and grown, local politicians opposed to wind power and sections of the media. An advocacy coalition in favour of ambitious renewables targets could hardly be discerned. The only other apparent force was the CDU, which was only prepared to accept a minor readjustment of renewables policies.

Within this public struggle, and given their strategic positions as described above, the CDU and FDP cabinet ministers had already agreed to reduce the target for the share of renewable energy in gross electricity consumption from $33 \%$ to $30 \%$. The struggle then became more personalised as the Saxon head of the FDP (at the same time the leader of the FDP parliamentary group) insisted on a further cut in the proportion of renewables. A final decision was taken by the coalition committee. While the FDP demanded a target of only $25 \%$, the CDU wanted to retain the $30 \%$ share as decided in cabinet. Although the CDU is the senior coalition partner, it did not wish to fight too intensively: CDU and FDP agreed to meet about halfway, choosing a target of $28 \%$. Remarkably, the contribution of wind power was disproportionately cut from 3500 to $2200 \mathrm{GWh} / \mathrm{a}$, removing a considerable source of tension from the conflict. Nevertheless, the FDP promised to go on fighting for an even slower development of wind power. Indeed, in the subsequent period, the government erected new hurdles against the expansion of wind energy.

As already mentioned, in the elections to the Saxon parliament held in August 2014, the FDP lost 6.2 percentage points of its previous share of the vote and thereby all its parliamentarians. In contrast, the CDU's share of the vote fell by only $0.8 \%$. It is beyond the scope of this study to analyse these results. Nevertheless, we can report an interesting interpretation by the chairman of the planning association [47]. In his view, because protests against wind power were confined to certain sites, this was not a key factor in the election results. Therefore, the energy policy pursued by the FDP seemed not to have boosted its election chances while, in contrast, the CDU was not harmed.

\section{Protests led to reduced targets for renewables; limitations of study}

In sum, the analysis of the empirical data regarding the comprehensive storyline and the motivations of the actors clearly shows that the protests against the ambitious renewables and wind power targets set by the government after the Fukushima disaster had a major impact on the reduction of these targets by Saxony's governing coalition committee. In order to judge more closely the impact of the protests on energy landscapes, it is helpful to attempt some overarching counterfactual analysis. Thus we pose the question: What would have happened if no or significantly weaker protests had occurred? The empirical data strongly suggests that the higher targets would not have been scaled back. The FDP would not have had the opportunity offered by the protests to distance itself from the new targets. While it cannot be ruled out that the party would have exploited other opportunities, the empirical material does not indicate what these could have been. Obviously, the CDU did not have a very strong original motivation to revise the higher targets announced by its own Prime Minister. Without the protest movement and a dissenting coalition partner, the CDU would not have come under the same pressure to revise the 33\% target for renewables. Nevertheless, changes might have been made with regard to the share of wind power within the $33 \%$ target. Therefore, we can say with a reasonable certainty that the protests were an insufficient but necessary condition for the scaling back of the targets for renewables. As the analysis of the dynamic process shows, the impact of the protests also depended on a specific configuration of additional factors, in particular:

- The widespread scepticism of wind power in Saxony and the role of lignite as a Saxon energy source,

- The rather spontaneous increase in the targets for renewables after the Fukushima disaster,

- The rapid breakdown of these targets into concrete areas for wind farms,

- The draft status of the energy and climate programme and the siting plan for wind farms (although the key target was announced in an official government declaration),

- The existence and commitment of skilful and wellresourced leaders in the protest initiatives,

- Upcoming elections, and

- The decision of the Saxon FDP (in charge of the ministry dealing with energy policy) to turn against its coalition partner, thus building a strong antiwind advocacy coalition.

Regarding the study limitations, it is important to note that we have merely investigated the readjustment of an official policy output rather than policy outcomes, i.e. the impact of protests on the actual deployment of wind power on the ground. While it is obvious that a reduction in designated sites for wind turbines will limit their maximum total number, at the same time the setting of targets 
and the related designation of sites does not guarantee that these targets will be met. The implementation of targets for renewables and wind power expansion depends on a range of factors such as informational and financial support or the approval of applications for individual wind farms. These factors can also be influenced by opponents of wind power. Therefore, it is possible that the government and/or other actors will hamper implementation so that, in the end, expansion targets are not only greatly reduced but it proves impossible even to meet these reduced targets. This would, of course, further slow the process of landscape change.

\section{Conclusion}

In order to contribute to the discussion on the role played by local anti-wind power initiatives in the development of energy landscapes, the study investigated the influence of such protests on the reduction of state expansion targets for renewables in Saxony between 2011 and 2013. Using the method of causal-process tracing, our qualitative case study has shown, to a reasonable degree of certainty, that the protests were successful and did indeed have an impact on state energy policy and, ultimately, on landscapes. This confirms the possibility of influence shown in an earlier case study [21].

The study substantiates the complex dynamic processes which enabled local protesters to influence the political decision-making of a state government. Well-organised activists worked through a range of channels across various contexts and levels of the politico-administrative system, in particular approaching a regional planning association and a wide range of influential politicians, e.g. in municipalities as well as in the Saxon parliament and government. However, the protests were not a sufficient condition to explain the policy readjustment; rather they were an important necessary factor within a specific constellation of other causal factors. These include the general sceptical attitude towards wind power in Saxony, the rather spontaneous increase of the renewables targets after the Fukushima disaster, the rapid breakdown of these targets into concrete areas for wind farms, upcoming elections, as well as the building of a strong advocacy coalition against the ambitious targets by the local anti-wind initiatives and the junior government coalition party in charge of the ministry dealing with energy policy.

Thus, the study adds to an emerging middle range theory of the impact of local opposition to wind power in the context of energy landscapes. The investigation goes significantly beyond previous studies which have largely focussed on participation in the planning of sites and the approval process of single wind farms. Although the presented case is unique, it highlights the potential relevance of various factors jointly influencing all levels and sectors of the politico-administrative system for energy- related landscape development. This is not only true for cases in which state energy targets are actually reduced, but also for those cases where low energy targets are chosen from the outset.

Drawing on the Advocacy Coalition Framework and including the Fukushima disaster into the investigation, the reduction of targets can be interpreted in a bigger context involving two defined paths to policy change. Regarding the first path, the Energiewende and the increase of targets for renewables in 2011 was triggered by an external shock, namely the Fukushima disaster. However, in Saxony the increased targets led to a growing opposition, and under the described circumstances, to a significant weakening of said targets. This confirms that external shocks may fail to trigger a fundamental shift in policy intentions and, in the end, policy change [cf. 25, p. 128]. Remarkably, the reversal came about through another defined path to policy change, i.e. negotiations within the coalition committee of the government representing the rivalling camps.

Finally, the study findings point to some wider implications. It could be argued, as the Saxon government implies, that the examined case provides an example of a well-functioning democracy and planning system that is sensitive to local protests: In this interpretation, the government made a miscalculation in energy and landscape policy, which was recognised and corrected during the attempted implementation by regional planning. However, from the point of view of global climate protection and climate justice, the end result is unsatisfying. Local protests, in combination with party politics and its associated dynamics, served to reduce targets for renewables. This obviously runs against the interests of all those who (will) suffer from global warming, particularly in the most vulnerable countries. From this perspective, local landscapes have been protected at the expense of the wellbeing of others. Although in the investigated case, the political party which most vigorously opposed wind power did not really benefit from its rather "populist" position, this may not discourage other parties in Saxony or elsewhere to exploit the attractive view that society does not need to undergo inconvenient (landscape) change for the purposes of climate protection or even that global warming is a fiction.

\section{Acknowledgements}

The authors are grateful to their colleague Peter Wirth and the three anonymous reviewers for their very helpful comments. In particular, the authors want to thank the interviewees for kindly providing valuable information. Thanks also to Derek Henderson for proofreading the text.

\section{Authors' contributions}

Since 2011 the authors have worked together in three successive IOER projects on landscape governance in the context of the German

Energiewende, particularly with regard to the conceptualisation of landscape governance, informal participation in regional planning and the politics of landscape change and management. As described in the section on 
methods, the first stage of empirical work was mainly conducted by ML. The second stage was mainly carried out by GL. The authors developed the concept of the paper together and jointly interpreted the results. The text was written primarily by GL in close cooperation with ML. Both authors read and approved the final manuscript.

\section{Funding}

The research was funded by the institutional budget of the Leibniz Institute of Ecological Urban and Regional Development.

\section{Availability of data and materials}

As described in the section on methods, the data used for the study was collected from many different sources. Most of these are publicly available such as the minutes of parliamentary debates or many individual newspaper articles. This data is available from the corresponding author upon reasonable request. The conducted interviews are confidential.

\section{Ethics approval and consent to participate}

Not applicable

\section{Consent for publication}

Not applicable

\section{Competing interests}

The authors declare that they have no competing interests.

Received: 16 April 2019 Accepted: 27 November 2019

Published online: 23 January 2020

\section{References}

1. Roth M et al (2018) Renewable energy and landscape quality. Jovis, Berlin

2. Selman P (2010) Learning to love the landscapes of carbon-neutrality. Landscape Res 35(2):157-171. https://doi.org/10.1080/01426390903560414

3. Hager C, Haddat MA (2015) Nimby is beautiful. Cases of local activism and environmental innovation around the world. Berghahn, New York

4. Ellis G, Barry J, Robinson C (2007) Many ways to say 'no', different ways to say 'yes': Applying Q-Methodology to understand public acceptance of wind farm proposals. J Environ Plann Manage 50(4):517-551. https://doi.org/ 10.1080/09640560701402075

5. Wolsink M (2007) Wind power implementation. The nature of public attitudes: Equity and fairness instead of 'backyard motives'. Renewable Sustainable Energy Rev 11(6):1188-1207. https://doi.org/10.1016/j.rser.2005. 10.005

6. Groth TM, Vogt C (2014) Residents' perceptions of wind turbines: An analysis of two townships in Michigan. Energy Policy 65:251-260. https:// doi.org/10.1016/j.enpol.2013.10.055

7. Suškevičs M et al (2019) Regional variation in public acceptance of wind energy development in Europe: What are the roles of planning procedures and participation? Land Use Policy 81:311-323. https://doi.org/10.1016/j. landusepol.2018.10.032

8. Firestone J, Hoen B, Elliott D, Hübner G, Pohl J (2018) Reconsidering barriers to wind power projects: community engagement, developer transparency and place. J Environ Policy Plann 20(3):370-386. https://doi.org/10.1080/ 1523908X.2017.1418656

9. Moss T, Becker S, Naumann M (2015) Whose energy transition is it, anyway? Organisation and ownership of the Energiewende in villages, cities and regions. Local Environ 20(12):1547-1563. https://doi.org/10.1080/13549839. 2014.915799

10. Cowell R, Bristow G, Munday M (2011) Acceptance, acceptability and environmental justice: the role of community benefits in wind energy development. J Environ Plann Manage 54(4):539-557. https://doi.org/10. 1080/09640568.2010.521047

11. Zilles J, Schwarz C (2015) Bürgerproteste gegen Windkraft in Deutschland. Organisation und Handlungsstrategien. Informationen zur Raumentwicklung 6:669-679 (no doi available)

12. Toke D, Breukers S, Wolsink M (2008) Wind power deployment outcomes: How can we account for the differences? Renewable Sustainable Energy Rev 12(4):1129-1147. https://doi.org/10.1016/j.rser.2006.10.02

13. Ogilvie $M$, Rootes $C$ (2015) The impact of local campaigns against wind energy developments. Environ Polit 24(6):874-893. https://doi.org/10.1080/ 09644016.2015 .1063301
14. Marg S, Zilles J, Schwarz C (2017) "Das Maß ist voll!" Proteste gegen Windenergie. In: Hoeft C, Messinger-Zimmer S, Zilles J (eds) Bürgerproteste in Zeiten der Energiewende. Lokale Konflikte um Windkraft, Stromtrassen und Fracking. Transcript Verlag, Bielefeld, pp 63-95

15. Reusswig F, Braun F, Heger I, Ludewig T, Eichenauer E, Lass W (2016) Against the wind: Local opposition to the German Energiewende. Utilities Policy 41:214-227. https://doi.org/10.1016/j.jup.2016.02.006

16. Alexander E (2008) Public participation in planning - A multidimensional model: The case of Israel. Planning Theory Pract 9(1):57-80. https://doi.org/ 10.1080/14649350701843853

17. Aitken M, McDonald S, Strachan P (2008) Locating 'power' in wind power planning processes: the (not so) influential role of local objectors. J Environ Plann Manage 51(6):777-799. https://doi.org/10.1080/09640560802423566

18. Rydin Y, Lee M, Lock SJ (2015) Public engagement in decision-making on major wind energy projects. J Environ Law 27:139-150. https://doi.org/10. 1093/jel/eqv001

19. Schreurs M, Ohlhorst D (2015) NIMBY and YIMBY. Movements for and against renewable energy in Germany and the United States. In: Hager C, Haddat MA (eds) (2015) Nimby is beautiful. Cases of local activism and environmental innovation around the world. Berghahn, New York, pp 60-86

20. Schmidt A, Zschiesche M (2018) Die umweltrechtliche Verbandsklage im Zeitraum von 2013 bis 2016 - Ergebnisse einer empirischen Untersuchung. Natur und Recht 40(7):443-452

21. Bues A (2018) Planning, protest, and contentious politics. The Governance of wind energy in Brandenburg and Ontario. DisP - The Planning Review 215(54.4):34-45. https://doi.org/10.1080/02513625.2018.1562796

22. Scharpf FW (1997) Games real actors play. Actor-centred institutionalism in policy research. Westview Press, Boulder

23. Schmidt V (2008) Discursive institutionalism: The explanatory power of ideas and discourse. Annu Rev Pol Sci 11:303-326

24. Healey P (2012) Communicative planning: Practices, concepts, and rhetorics In: Sanyal B, Vale LJ, Rosan CD (eds) Planning ideas that matter. MIT, Cambridge/London, pp 333-357

25. Sabatier PA, Weible CM (2007) The advocacy coalition framework: Innovations and clarifications. In: Sabatier Theories of the policy process. Westview Press, Boulder, pp 189-220

26. Sabatier PA, Jenkins-Smith H (1999) The advocacy coalition framework: An assessment. In: Sabatier PA (ed) Theories of the policy process. Westview Press, Boulder, pp 117-166

27. Weible CM, Sabatier PA, Mcqueen K (2009) Themes and variations: Taking stock of the advocacy coalition framework. Policy Stud J 37(1):121-140. https://doi.org/10.1111/j.1541-0072.2008.00299.x

28. Blatter J, Haverland M (2014) Designing case studies. Explanatory approaches in small-N research. Palgrave Macmillan, Basingstoke

29. Leibenath M, Wirth P, Lintz G (2016) Just a talking shop? Informal participatory spatial planning for implementing state wind energy targets in Germany. Utilities Policy 41:206-213. https://doi.org/10.1016/j.jup.2016.02.008

30. Regionaler Planungsverband Oberes Elbtal/Osterzgebirge (2013) Energieund Klimaprogramm als wichtige Planungsgrundlage für die Findung zukünftiger Windenergiestandorte ist da - Maßgaben bei der Standortfestlegung jedoch für die Planungsverbände wenig hilfreich. Pressemitteilung vom 14(03):2013

31. Kleinhückelkotten S, Neitzke HP (2012) Naturbewusstseinsstudie 2011. Abschlussbericht. ECOLOG-Institut für sozial-ökologische Forschung und Bildung, Hannover

32. Leibenath M, Lintz G (2018) Understanding "landscape governance". The case of wind energy landscapes in Germany. Landscape Res 43(4):476-488. https://doi.org/10.1080/01426397.2017.1306624

33. Quitzow L, Canzler W, Grundmann P, Leibenath M, Moss T, Rave T (2016) The German Energiewende - What's happening? Introducing the special issue. Utilities Policy 41(August 2016):163-171. https://doi.org/10.1016/j.jup. 2016.03.002

34. SAENA - Sächsische Energieagentur (2018) Gutachten EE-Aubaupotenziale in Sachsen. Available under http://www.energie.sachsen.de/download/ energie/Gutachten-EE-Ausbaupotentiale-in-Sachsen-final.pdf. Accessed 3 Apr 2019

35. Sächsischer Landtag (Hrsg.) (2011) Plenarprotokoll 5/36, 36. Sitzung Mittwoch 25. Mai 2011. Darin: Regierungserklärung zum Thema: „Energieland Sachsen - solide, nachhaltig und innovativ, 3437-3469

36. Staatsministerium für Umwelt und Landwirtschaft, Freistaat Sachsen (Hrsg.) (2009): Aktionsplan Klima und Energie des Freistaates Sachsen, 
Redaktionsschluss: 20.11.2009, Dresden. https://publikationen.sachsen.de/ bdb/artikel/11715. Accessed 17 Sept 2019

37. Staatsministerium für Wirtschaft, Arbeit und Verkehr und Staatsministerium für Umwelt und Landwirtschaft, Freistaat Sachsen (Hrsg.) Energie- und Klimaprogramm Sachsen (Entwurf, Stand 12. Oktober 2011), Dresden. https://www.medienservice.sachsen.de/medien/medienobjekte/ 91224? page $=24$. Accessed 17 Sept 2019

38. Staatsministerium für Wirtschaft, Arbeit und Verkehr und Staatsministerium für Umwelt und Landwirtschaft, Freistaat Sachsen (Hrsg.) Energie- und Klimaprogramm Sachsen 2012 vom 12. März 2013, Dresden. https://www. klima.sachsen.de/energie-und-klimaprogramm-sachsen-22623.html. Accessed 17 Sept 2019

39. Ohlhorst D (2009) Windenergie in Deutschland. Konstellationen, Dynamiken und Regulationspotenziale im Innovationsprozess. VS Verlag für Sozialwissenschaften, Wiesbaden

40. Morris C, Jungjohann A (2016) Energy democracy. Germany's Energiewende to renewables. Palgrave Macmillan, Cham

41. Interview with an expert of the Saxon Energy Agency (SAENA), who in this case worked for the Saxon Economic Ministry responsible for energy policy (led by the Liberal Democrats, FDP), Dresden, 26 October 2018

42. Sächsischer Landtag (Hrsg.) (2011) Plenarprotokoll 5/44, 44. Sitzung, Mittwoch 23. November 2011. Darin: 1. Aktuelle Debatte: Bezahlbar - sicher umweltfreundlich: Zukunftsfähige Energieversorgung für Sachsen, Antrag der Fraktionen der CDU und der FDP, 4352-4362

43. Regionaler Planungsverband Oberes Elbtal/Osterzgebirge (2011) Stellungnahme zum Entwurf des Energie- und Klimaprogramms Sachsen (Entwurf, Stand 12.10.2011), Entwurf, beschlossen auf der 36. Verbandsversammlung

44. Verbandsgeschäftsstelle des Regionalen Planungsverbands Oberes Elbtal/ Osterzgebirge (Hrsg.) (2010): Wissenswert - ein Infoservice, Ausgabe Nr. 2, Oktober 2010

45. Sächsischer Landtag (Hrsg.) (2012) Plenarprotokoll 5/49, 49. Sitzung, Donnerstag, 26. Januar 2012, Darin: Energie- und Klimaprogramm Sachsen 2020, Drucksache 5/7778, Antrag der Fraktion DIE LINKE, $4933-4949$

46. Interview with the head of the planning bureau of the regional planning association Upper Elbe/East Ore Mountains, Radebeul, 12 September 2018

47. Interview with the chairman of the regional planning association Upper Elbe/East Ore Mountains who is also the head of an administrative district and a member of the Christian Democratic Party (CDU), Pirna, 9 January 2019

48. Verbandsgeschäftsstelle des Regionalen Planungsverbands Oberes Elbtal/ Osterzgebirge (Hrsg.) (2011): Wissenswert - ein Infosenvice, Ausgabe Nr. 3, Juli 2011

49. Verbandsgeschäftsstelle des Regionalen Planungsverbands Oberes Elbtal/ Osterzgebirge (Hrsg.) (2011): Wissenswert - ein Infoservice, Ausgabe Nr. 4, Dezember 2011

50. Interview with a representative of the Saxon wind power industry, Dresden, 28 May 2014

51. Deider K (2012) Krach um die Windkraft in Großenhain. Mit Schirmen und Luftballons wehren sich Anwohner gegen den Bau von Deutschlands größtem Windpark - nicht ohne Erfolg. Sächsische Zeitung, sz-online, 20. Mai 2012. http://gegenwindheide.blogsport.de/presse/krach-um-diewindkraft-in-grossenhain-sz-20-05-2012/. Accessed 17 Sept 2019

52. Interview with a representative of an anti-wind power initiative, Dresden, 23 September 2014

53. Interview with the head of the planning bureau of the regional planning association Upper Elbe/East Ore Mountains, Radebeul, 19 December 2014

54. Ohne Verfasser (2012) Anwohner machen sich für Vogelschutz stark. Sächsische Zeitung, 9. März 2012. http://gegenwindheide.blogsport.de/ presse/anwohner-machen-sich-fuer-vogelschutz-stark-sz-09-03-2012/. Accessed 17 Sept 2019

55. Ohne Verfasser (2012) Windkraft in Sachsen - ein Sturm der Entrüstung zieht auf. Die Energiewende wird auch bei uns ihre Spuren hinterlassen. Schon regt sich erster Widerstand. Morgenpost am Sonntag, 25.03.2012. http://gegenwindheide.blogsport.de/images/20120325_mopo_windreport. pdf. Accessed 17 Sept 2019

56. Regionaler Planungsverband Oberes Elbtal/Osterzgebirge (2012) Niederschrift zur 37. Sitzung der Verbandsversammlung des Regionalen Planungsverbands Oberes Elbtal/Osterzgebirge (öffentlich) am 28.03.2012 vom 08.05.2012

57. Ulbricht B (2012) Windräder spalten die Region. Sächsische Zeitung vom 12. 04.2012. http://gegenwindheide.blogsport.de/presse/windraeder-spaltendie-region-sz-12-04-2012/. Accessed 17092019
58. Ohne Verfasser (2012) Kleinnaundorf/Dobra. Bürger bilden Netzwerk: Die Bürgerinitiativen wollen für größere Mindestabstände kämpfen. Sächsische Zeitung, 11.05.2012, https://www.genios.de/presse-archiv/artikel/SZO/ 20120511/kleinnaundorf-dobra-buerger-bilden-/12733036.html. Accessed 17 Sept 2012

59. Verbandsgeschäftsstelle des Regionalen Planungsverbands Oberes Elbtal/ Osterzgebirge (Hrsg.) (2012): Wissenswert - ein Infoservice, Ausgabe Nr. 5, Juni 2012

60. Sächsischer Landtag, Innenausschuss (Hrsg.) (2012) Protokoll der 33. Sitzung des Innenausschusses am 24.5.2012, Öffentliche Anhörung zum Landesentwicklungsbericht und zum Entwurf des Landesentwicklungsplans 2012, Block III, 6. Juni 2012

61. Interview with two civil servants of the CDU-led Saxon Ministry of the Interior in the field of spatial planning, Dresden, 24 October 2018

62. Ohne Verfasser (2012) Information zur Alternativen Klimakonferenz der FDPFraktion am 30. Juni 2012 in Dresden. https://www.fdp-erzgebirge.de/ alternative-klimakonferenz-der-fdp-fraktion-am-30-juni-2012-in-dresden/. Accessed 18 Sept 2019

63. Sächsischer Landtag (Hrsg.) (2012) Plenarprotokoll 5/60, 60. Sitzung, Donnerstag, 12. Juli 2012. Darin: 1. Aktuelle Debatte: Energiepolitik mit Augenmaß - Stromrechnung für Bürger und Unternehmen bezahlbar halten, Antrag der Fraktionen der CDU und der FDP, 6038-6052

64. Ulbricht B (2012) "Was wir erleben, ist Planwirtschaft". Jan Mücke (FDP) ist gegen das Windkraftprojekt in Strauch. Er tritt für den Landschaftsschutz ein und sieht steigende Strompreise voraus. Sächsische Zeitung, 22.08.2012, 16

65. Sächsischer Landtag (Hrsg.) (2012) Plenarprotokoll 5/64, 64. Sitzung, Mittwoch 17. Oktober 2012. Darin: 1. Aktuelle Debatte: Kostenexplosion bei erneuerbaren Energien stoppen - Förderung reformieren, Stromsteuer für Verbraucher senken, Antrag der Fraktionen der CDU und der FDP, 64246442

66. Rischke, L (2012) Erneuerbare Energien sorgen für Streit in der Koalition. Zastrow hält Ausbauziele für zu hoch / FDP-Chef kündigt Abstandsregelungen für Windkraftanlagen in Bauordnung an. Dresdner Neueste Nachrichten, 30.10.2012, 4

67. Kretschmer, M (2012) Erklärung des Generalsekretärs der Sächsischen Union, 30.10.2012, https://www.cdu-kreistag-meissen.de/inhalte/2/aktuelles/29869/kretschmer-zu-den-aeusserungen-der-fdp-/index.html. Accessed 23 Oct 2018

68. Ulbricht B (2012) Strauch/Stroga. Windparkplaner und Bürger reden miteinander: Nüchtern betrachtet ist keine Forderung der Bürger zum Windpark erfültt. Sächsische Zeitung, 16.10.2012, http://www.sz-online.de/ nachrichten/windparkplaner-und-buerger-reden miteinander-1605366.html. Accessed 25 Mar 2013

69. Ohne Verfasser (2012) Großenhain. Windparks fallen aus oder werden kleiner. Sächsische Zeitung 20.11.2012, http://www.sz-online.de/nachrichten/ windparks-fallen-aus-oder-werden-kleiner-2451636.html. Accessed $25 \mathrm{Mar}$ 2013

70. Pleil I (2012) Windenergieplanung liegt auf Eis. Fehlende Vorgaben des Landes machen Standort-Eingrenzung für Elbregion unmöglich. Dresdner Neueste Nachrichten, 22.11.2012, 4

71. Verbandsgeschäftsstelle des Regionalen Planungsverbands Oberes Elbtal/ Osterzgebirge (Hrsg.) (2012): Wissenswert - ein Infoservice, Ausgabe Nr. 6, Dezember 2012

72. Ohne Verfasser (2012) Information zur Alternativen Energiekonferenz der FDP-Fraktion im Sächsischen Landtag am 01.12.2012 in Dresden, mit Link zum Konferenz-Video, http://rennersdorfer-gegenwind.de/alternativeenergiekonferenz-dresden/. Accessed 18 Sept 2019

73. Sächsischer Landtag (Hrsg.) (2012) Plenarprotokoll 5/68, 68. Sitzung, Freitag, 14. Dezember 2012. Darin: 2. Aktuelle Debatte: Sächsischer Klimaschutz Rückwärts immer, vorwärts nimmer? Antrag der Fraktionen Bündnis 90/DIE GRÜNEN, 7015-7030

74. Regionaler Planungsverband Oberes Elbtal/Osterzgebirge (2013) Regionaler Planungsverband befürwortet weiterhin Steuerung der Windenergienutzung in der Region. Pressemitteilung vom 23(01):2013

75. Sächsischer Landtag, Verwaltung (Hrsg.) (2013) Stenografisches Protokoll der Anhörung durch den Innenausschuss am 28. Februar 2013 zum Landesentwicklungsplan 2012, Geänderter Entwurf für das ..., 7. März 2013

76. Kochinke (2013) Sachsen tritt bei erneuerbaren Energien auf die Bremse. Kompromiss im Zwist zwischen CDU und FDP: Koalition will Zielmarke von 30 auf 28 Prozent senken - gestreckt bis 2015. Dresdner Neueste Nachrichten, 07.03.2013, 4

77. Email from the former Saxon Prime Minister to the authors, 8 January 2019 
78. Staatsministerium den Innern (Hrsg.) (2013) Landesentwicklungsplan 2013 vom 12. Juli 2013, Dresden

79. Pleil I (2013) Region Oberes Elbtal-Osterzgebirge. "Unsäglicher Erlass" Windkraftplanung ausgebremst. Dresdner Neueste Nachrichten, 27.09.2013, 4

80. Pleil I (2013) Verbandschef Geisler kritisiert Energiekonzept. Land erweckt bei Windkraftgegnern falsche Hoffnungen. Dresdner Neueste Nachrichten, 15.03.2013, 5

81. Verbandsgeschäftsstelle des Regionalen Planungsverbands Oberes Elbtal/ Osterzgebirge (Hrsg.) (2013): Wissenswert - ein Infoservice, Ausgabe Nr. 10, Juli 2013

82. Verbandsgeschäftsstelle des Regionalen Planungsverbands Oberes Elbtal/ Osterzgebirge (Hrsg.) (2013): Wissenswert - ein Infoservice, Ausgabe Nr. 11, Oktober 2013

83. Gerring J (2012) Case study research. Principles and practices (14 ${ }^{\text {th }}$ printing). Cambridge University Press, Cambridge

84. Interview with an expert working for the Green Party (Grüne), which was an opposition party in the Saxon parliament, Dresden, 16 August 2018

85. Sächsischer Landtag (Hrsg.) (2010) Plenarprotokoll 5/22, 22. Sitzung, Donnerstag, 30. September 2010. Darin: 1. Aktuelle Debatte: Sichere bezahlbare und saubere Energie für Sachsen, Antrag der Fraktionen der CDU und der FDP, 1932-1953

86. Sächsischer Landtag (Hrsg.) (2012) Plenarprotokoll 5/60, 60. Sitzung, Donnerstag, 12. Juli 2012, Darin: Landesentwicklungsplan 2012, Entwurf für das Beteiligungsverfahren gemäß ..., 6061-6073

87. Sächsischer Landtag (Hrsg.) (2013) Plenarprotokoll 5/77, 77. Sitzung, Donnerstag, 16. Mai 2013. Darin: Energiearmut verhindern statt Energiewende ausbremsen! Drucksache 5/11683, Antrag der Fraktionen Bündnis 90/DIE GRÜNEN, mit Stellungnahmen der Staatsregierung, 79958009

88. Sächsischer Landtag (Hrsg.) (2013) Plenarprotokoll 5/77, 77. Sitzung, Donnerstag, 16. Mai 2013. Darin: Landesentwicklungsplan 2012, Geänderter Entwurf für das Beteiligungsverfahren gemäß ..., 8016-8022

89. Eilenberger M (2013) Heimat im Wandel - Erneuerbare Energieträger und Kulturlandschaft. Manuskript der Rede, gehalten 12.10.2013 anlässlich des 4. Sächsischen Heimattags "Heimat - aktiv". http://www.sachsen-gegenwind. de/mediadata/images/inhalte/05_Rede\%20M\%20E\%20\%20\%2012\%2010\% 2013.pdf. Accessed 01 Oct 2019

90. Schlottmann, K (2013) Sachsen fordert strengere Vorschriften für Windräder. Windkraft ist ein idealer Winderzeuger - wenn nicht die großen Windräder wären. Die Proteste in einigen Regionen haben offenbar Erfolg. Sächsische Zeitung, 13.03.2013, 19

91. Kositz S (2019) Zoff in der Dresdner FDP: Partei stellt sich gegen Fraktion und deren Chef Zastrow. Interview mit Holger Hase. Dresdner Neueste Nachrichten, 27.04.2019, https://www.dnn.de/Dresden/Lokales/Zoff-in-derDresdner-FDP-Partei-stellt-sich-gegen-Fraktion-und-deren-Chef-Zastrow. Accessed 30 Aug 2019

92. CDU-Fraktion des Sächsischen Landtags: CDU-Energieexperte: "Eigenständiger Weg Sachsens gut und richtig", Beitrag vom 12.03.2013, https://www.cdu-fraktion-sachsen.de/aktuell/pressemitteilungen/meldung/ cdu-energieexperte-eigenstaendiger-weg-sachsens-gut-und-richtig.html. Accessed 18 Sept 2019

\section{Publisher's Note}

Springer Nature remains neutral with regard to jurisdictional claims in published maps and institutional affiliations.

Ready to submit your research? Choose BMC and benefit from:

- fast, convenient online submission

- thorough peer review by experienced researchers in your field

- rapid publication on acceptance

- support for research data, including large and complex data types

- gold Open Access which fosters wider collaboration and increased citations

- maximum visibility for your research: over $100 \mathrm{M}$ website views per year

At BMC, research is always in progress.

Learn more biomedcentral.com/submissions 